\title{
Institutions, Banking Structure, and The Cost of Debt: New International Evidence $^{\text {a }}$
}

\author{
Celia Álvarez-Botas. \\ Víctor M. González \\ Department of Business Administration \\ University of Oviedo
}

JEL Code: G31, G38

Key words: Cost of debt, institutions, depth of credit information, banking structure.

\footnotetext{
${ }^{a}$ We wish to thank participants at the ACEDE Conference in Vigo (2016) for helpful comments and suggestions. Funding from the Spanish Ministry of Economy and Competitiveness via Project ECO201566184-R and financial support from the Government of the Principality of Asturias via the Severo Ochoa programme of pre-doctoral grants are gratefully acknowledged.

${ }^{b}$ Corresponding author: Víctor M. González. Department of Business Administration. University of Oviedo. Avda. del Cristo s/n. 33071 Oviedo. E-mail: vmendez@uniovi.es
} 


\title{
INSTITUTIONS, BANKING STRUCTURE, AND THE COST OF DEBT: NEW INTERNATIONAL EVIDENCE
}

\author{
Abstract \\ This paper analyses the effect of institutions and the structure of the banking system on the cost \\ of debt for a sample of firms from 37 countries. The cost of debt decreases with the rule of law, \\ the protection of creditors' rights, and the weight of banks in the economy. The bank financing \\ and bank concentration have a positive differential effect on the cost of debt in those countries \\ where the financial difficulties of banks are greater. Legal enforcement, the protection of \\ creditors' rights and the weight of bank financing have a greater influence in countries with a \\ lower degree of economic development.
}




\section{INSTITUTIONS, BANKING STRUCTURE, AND THE COST OF DEBT: NEW INTERNATIONAL EVIDENCE}

\section{Introduction}

In recent decades, the financial literature on firm capital structure has focused on legal and institutional determinants, based on the premise that access to external financing depends partly on the legal and institutional system of each country, as this provides the mechanisms to monitor and ensure financial contracts. This literature (Giannetti, 2003; Gaud et al., 2005; de Jong et al., 2008; González and González, 2008; Öztekin and Flannery, 2012; and Gungoraydinoglu et al., 2017, among others) has generally shown that the protection of creditor rights, the protection of shareholder rights, corruption, the political environment, and bank concentration have an influence on firm leverage.

The analysis of the influence of legal and institutional quality has not only focused on the level of firm leverage, but has also addressed the influence that this has on debt maturity. DemirgüçKunt and Maksimovic (1999), Fan et al. (2012), and González (2017) examine the influence of institutions on firm debt maturity. They show that firms in countries that are viewed as more corrupt tend to use more short-term debt. Fan et al. (2012) also provide evidence that the debt maturity structure of companies in countries with a larger banking sector tends to be shorter. González (2017) shows that bank concentration has a positive influence on corporate debt maturity, revealing that creditors are more likely to extend debt maturity when the bank credit market is concentrated.

This literature has thus highlighted the importance of the legal and institutional quality and banking structure of countries when taking decisions about firm capital structure. In this context, the aim of the present paper is to study the influence of legal and institutional variables and the banking structure on the cost of corporate debt. 
The background to this paper can be found in the articles by Qian and Strahan (2007) and Bae and Goyal (2009), who analysed the importance of institutional quality in explaining the different terms of bank loans. In particular, Qian and Strahan (2007) show that, under strong creditor protection, loans have more concentrated ownership, longer maturities, and lower interest rates. These results paint a clearer picture of how creditor protection generates good financial outcomes. With better protection, lenders can control borrower risk because they know they will be able to take assets -or credibly threaten to take assets-ex post in the event of default. Bae and Goyal (2009) show that property rights result in more efficient contracting. Banks lend more, offer longer maturities, and charge lower spreads on loans to borrowers in countries where property rights are well protected.

This paper studies the effects of laws, institutions, and the banking structure on the cost of debt. Specifically, we analyse the impact of variables such as rule of law, creditor rights, depth of credit information, bank financing, and bank concentration. Our results are based on a fairly large sample of firms from the Worldscope Database that allows us to identify the cost of debt from balance data and the profit and loss account. This database enables us to analyse smaller firms compared to the database used in the articles by Qian and Strahan (2007) and Bae and Goyal (2009).

The study provides a number of contributions to the literature. First, it extends the evidence provided by Qian and Strahan (2007) and Bae and Goyal (2009), considering not only the protection of creditor and property rights, but also variables that were not considered in the aforementioned papers that will potentially have an influence on the conditions of debt, such as those that form the structure of a country's banking system, namely the weight of bank financing and bank concentration. González and González (2008) and Fan et al. (2012) have shown that bank concentration and bank financing respectively influence leverage and debt maturity. Furthermore, we also consider the effect of sharing credit information. Pagano and Japelli (1993) and Padilla and Pagano (2000) show that information sharing helps in selecting good borrowers and overcoming moral hazard problems. However, these aspects have not been analysed with 
respect to the cost of debt.

Second, we also consider the solvency level of banks in the aforementioned analysis. The financial condition of banks is crucial for economies, as it may have consequences for business activity (Dell'Ariccia et al., 2008), although its consequences for depositors could be alleviated by the existence of deposit insurance schemes. In the wake of the financial crisis, several studies have shown its consequences on the corporate sector, revealing that new lending decreased substantially across all types of loans (Almeida et al., 2011; Campello et al., 2010; Duchin et al., 2010; González, 2015; Ivashina and Scharfstein, 2010; Santos, 2011). Following the predictions of the Rajan (1992) model, Santos and Winton (2008) find that banks raise their rates more for bank-dependent firms than for nonbank-dependent firms during recessions, suggesting increases in information hold-up problems that informed banks are able to exploit. If borrowing firms are unable to substitute bank loans by alternative sources of external financing, shocks affecting the financial health of banks may impose significant costs on the non-financial sector. Given that the financial crisis has greatly affected the solvency of financial institutions, we considered it relevant to analyse whether the effect of the structure of the banking system on the cost of debt has changed as a function of the solvency of banks.

Third, we also distinguish according to the level of economic development of each country. Developing countries are characterized by poorer institutions and less information disclosure, which could increase the intensity of information asymmetries (Levine et al., 2000; Claessens and Laeven, 2003). Information asymmetries have a major influence on the cost of debt and could affect it differently depending on the degree of development of the country. The existence of more asymmetric information in developing countries can lead to institutions playing a more important role in these countries compared to developed countries. Therefore, we analyse whether laws, institutions, and the structure of the banking system affect the cost of debt differently depending on the level of economic development of the country.

Our results show that the cost of debt decreases with stronger rule of law, stronger protection of 
creditor rights, and a greater weight of banks in the economy. Furthermore, our results show that bank concentration and the weight of bank financing have a positive differential effect on the cost of debt in those countries where banks faced greater financial difficulties. Finally, the effect of laws, institutions, and the weight of bank financing differs depending on the level of economic development. Specifically, the quality of institutions and the weight of bank financing have a greater influence in countries with a lower degree of economic development.

The rest of the paper is organized as follows. Section 2 reviews the related literature and develops testable hypotheses on laws, institutions, and the banking structure as determinants of the cost of debt. Section 3 describes our data and presents the descriptive statistics of the variables. Section 4 reports the empirical results and the subsequent robustness analysis, while Section 5 concludes the paper.

\section{Hypotheses}

\subsection{Laws and institutions}

The forecasted effect of rule of law on the cost of debt is that the higher the degree of rule of law, i.e. the higher the efficiency of its legal system, the safer the country will be with regard to investing in it. This is because creditors will have greater guarantees in the sense that there is more likelihood that the counterparty will meet the conditions set out in the financial contract. This circumstance means that lenders will be willing to demand lower interest rates than may be required in countries where the degree of rule of law is lower. Demirgüç-Kunt and Maksimovic (1999) show that large firms in countries with effective legal systems have more long-term debt with respect to assets and that their debt is of longer maturity. Bae and Goyal (2009) find an inverse relationship between property rights and the cost of bank loans. Hence, in those countries where property rights are well protected, the cost of bank loans is lower. Considering the rule of law obtained from the World Bank's Worldwide Governance Indicators (WGI) database as a measure of legal enforcement (R_LAW), the first hypothesis is thus as follows:

Hypothesis 1: We expect greater legal enforcement to reduce the cost of debt. 
Stronger protection of creditors' rights gives lenders greater power in the case of bankruptcy and hence the risk they assume will be lower. Moreover, it increases the incentives of borrowers to repay loans and avoid bankruptcy situations. When creditors are highly protected, to the extent that they can replace the management team of a company, bankruptcy generates high costs for the company. This reduces the likelihood of the company taking high risks, and thus moral hazard problems may decrease. Therefore, lenders will be willing to offer credit at a lower cost. Qian and Strahan (2007) show that bank loans have more concentrated ownership, longer maturities, and lower interest rates under strong creditor protection. The protection of creditors' rights (LEG_IND) has been measured by the strength of legal rights index drawn up by the World Bank's Doing Business database (Sorge et al., 2017; Qian et al., 2018). The second hypothesis is thus as follows:

Hypothesis 2: We expect a higher protection of creditors' rights to reduce the cost of debt.

The effective protection of creditors' rights could require not only that these rights are explicitly protected, but also that the degree of legal enforcement enables the exercise of such rights. For this reason, we consider the interaction between rule of law and the protection of lenders and borrowers' rights. An inverse and significant relationship between this interaction term and the cost of debt would indicate that it is not only necessary to be protected by law, but also that the justice system needs to work efficiently if the rules are not obeyed, which ultimately leads to a reduction in the cost of debt. A direct and significant relationship of the interaction term, on the other hand, would indicate that both legal enforcement and the protection of creditors' rights are alternative mechanisms to reduce the cost of debt. The interaction term could also be nonsignificant, which would mean that there is no joint effect between the two variables.

\subsection{Depth of credit information}

When a bank evaluates a request for credit, it can either collect information on the applicant firsthand with the aim of making a decision as to the adequacy of the loan, or source this information from institutions that record the characteristics of borrowers, their credit history 
(positive/negative), and the debt they have contracted with other lenders. Several studies find that information sharing helps lenders select good borrowers (Pagano and Jappelli, 1993) and overcome the moral hazard of borrowers (Padilla and Pagano, 2000).

The existence of credit information has at least two effects on the reduction of the cost of debt. First, the sharing of information reduces information asymmetries when creditors make decisions on lending. By reducing information asymmetries, creditors will be able to select lower-risk borrowers, thus reducing the problem of adverse selection, which will in turn contribute to better loan conditions. Second, the existence of a register of information will encourage borrowers to comply with conditions, thereby solving moral hazard problems. If the company fails to meet the stipulated conditions, the lender will share this information with other lenders, leading to higher financing costs for the company in future loans. ${ }^{1}$ Following Sorge et al. (2017), we consider the depth of credit information index as a measure of the depth of credit information (DEP_INF). The data are collected from the World Bank Doing Business database. The third hypothesis is thus as follows:

Hypothesis 3: Greater depth of credit information is associated with a lower cost of debt.

On the other hand, information sharing may interact with creditor rights in affecting the cost of debt. Better information sharing and stronger creditor rights are mechanisms that help creditors reduce credit risk. The impact of information sharing on the cost of debt may be weaker in countries with stronger creditor rights. In this regard, Sorge et al. (2017) show that when creditors have strong power ex post, e.g. to replace the management of firms in the case of bankruptcy, they may be willing to lend long-term in the absence of information sharing. In this context, we could expect better ex ante credit information to be a substitute for stronger ex post protection for

\footnotetext{
${ }^{1}$ Brown et al. (2009) analyse the influence of information sharing on the cost of financing in the transition countries of Eastern Europe and the former Soviet Union. However, they do not use the cost of debt. Instead, they consider the dependent variable to be the answer to the question: "How problematic is the cost of finance (e.g. interest rates and charges) for the operation and growth of your business?" (1=major obstacle, $2=$ moderate obstacle, $3=$ minor obstacle, $4=$ no obstacle). The measure of this variable comes from the Business Environmental and Enterprise Performance Survey (BEEPS).
} 
creditor rights in affecting the cost of debt, the coefficient of the interaction term being positive. However, an inverse relationship between this interaction and the cost of debt would indicate a complementary effect between the depth of credit information and the protection of lenders and borrowers' rights. This would mean that it is not only necessary for lenders and borrowers to be protected by law, but also that credit information should be available. In that case, the coefficient of the interaction term will be negative, suggesting a complementary effect between depth of credit information and protection of creditors' rights. The interaction term could also be nonsignificant, which would mean that there would be no joint effect between the two variables.

\subsection{Banking structure}

The banking literature suggests that the banking structure may affect information asymmetries in a country (Diamond, 1984; Fama, 1985). We consider two variables proxying banking structure: the weight of banks in the financing of the economy, and bank concentration. As regards the former, the increased participation of financial institutions in the economy, coupled with their role in reducing information asymmetries and agency costs, implies better expertise and an enhanced capacity to evaluate the quality of borrower projects, thereby leading to a reduction in the cost of debt. As a proxy for the weight of bank financing, we consider the ratio of private credit by deposit money banks and other financial institutions to GDP (B_CREDIT), obtained from the World Bank's Financial Structure database (Beck et al., 2006; Djankov et al., 2007; González, 2015). Based on this argument, our fourth hypothesis is as follow:

Hypothesis 4: We expect a higher weight of banks in financing to reduce the cost of debt.

As for the bank concentration variable, two potential effects on the cost of corporate debt may be posited. First, as greater concentration means less competition and greater market power, this would lead to a higher cost for borrowed funds. Second, in an environment characterized by the existence of information asymmetries, greater bank concentration and less competition may increase the incentives of banks to invest in the acquisition of soft information by establishing close relationships with borrowers over time. This would in turn result in a lower cost of debt as 
a consequence of the reduction in information asymmetries (Boot, 2000; Dell'Ariccia and Marquez, 2004). The importance of bank concentration has been argued by Petersen and Rajan (1995), showing that US firms in less concentrated credit markets are subject to greater financial constraints. These authors offer evidence from small business data indicating that creditors are more likely to finance credit-constrained firms when the credit markets are concentrated, because it is easier for these creditors to internalize the benefits of assisting firms. More recently, Barath et al. (2011) show the benefits of borrowing from relationship lenders even for large firms with a much wider choice of available financing options. González (2017) shows that corporate debt maturity increases with bank concentration. The existence of a positive relationship between bank concentration and debt maturity is in line with the fact that relationship banking serves to mitigate information asymmetries between creditors and debtors. Bank concentration (B_CONC) has been measured as the percentage of assets of the three largest banks as a share of the assets of all commercial banks (Beck et al., 2006; Demirgüç-Kunt et al., 2004). The data were obtained from the World Bank's Financial Structure database. As both a positive and negative influence of the degree of bank concentration on the cost of corporate debt may be expected, our expectations remain open and so we pose two hypotheses:

Hypothesis 5a: We expect a higher level of bank concentration to increase the cost of debt in view of the greater market power of banks.

Hypothesis 5b: We expect a higher level of bank concentration to reduce the cost of debt taking into account the establishment of long-term relationships between banks and lenders.

The solvency of financial institutions has been particularly affected during the Global Financial Crisis. We considered it relevant to analyse whether the effect of the banking structure on the cost of debt has been affected by the solvency of financial institutions. Previous studies have shown that new lending decreased substantially during the financial crisis (Ivashina and Scharfstein, 2010), corporate investment was reduced (Almeida et al., 2011; Campello et al., 2010), debt 
maturity was found to decline (González, 2015), and loans spreads were also shown to rise during the crisis (Santos, 2011). As firms suffer an increase in the risk of failure during recessions and hold-up problems increase with borrower risk, banks that have an exploitable information advantage should be able to raise their rates to a greater extent in recessions than is justified by borrower risk (Santos and Winton, 2008). Hence, we expect the favourable effect of the weight of bank financing on the cost of debt to be attenuated in recessions, mainly in those cases in which the solvency of the country's banks is more affected. Similarly, with respect to the effect of bank concentration, we may expect banks to take advantage of their market power, especially in those cases in which they have greater solvency problems. Therefore, we may expect a more negative effect or a lower positive effect of bank concentration on the cost of debt if banks have greater solvency problems. In line with this argument, Espenlaub et al. (2012) examines Thai nonfinancial companies during 1995-2000, a period straddling the East Asian Financial Crisis of 1997-1998. Their results suggest that, while bank connections facilitated corporate investment by reducing the financial constraints faced by companies in the pre-crisis period, they lost their value in the post-crisis period. We measure the solvency of the bank system using the percentage of bank non-performing loans to total gross loans (NPL) obtained from the World Bank's database. ${ }^{2}$ Papers such as Allen et al. (2014), Barth et al. (2004), Bruha and Kocenda (2018), Chen et al. (2018), González (2005), Jimenez et al. (2013), and Stojanovic et al. (2008) have used this variable as a proxy for the quality of bank assets and, more generally, as a proxy for banking system stability. A higher value of the ratio of NPL to total gross loans indicates a degradation of the quality of the assets held by the banks in a country. Moreover, the proportion of NPL is also a good predictor of systemic banking vulnerabilities (Cihák and Schaeck, 2010). In line with the

\footnotetext{
${ }^{2}$ We consider two additional measures of the solvency problems of banks. First, a dummy variable that takes the value of 1 if country $i$ goes through a banking crisis in year $t$, and zero otherwise. We have taken this variable from Laeven and Valencia (2012). The second variable considered is the bank Z-score, which captures the probability of default of a country's banking system. The higher the value of the bank Z-score, the greater the solvency of the country's financial institutions. Laeven and Levine (2009) and Cubillas et al. (2017), among others, have used the Z-score as a proxy for bank insolvency risk. The bank Z-score was obtained from the World Bank's Financial Structure database. Both variables have allowed us to provide robustness to our analysis, insofar as that the results (not reported for the sake of brevity) are similar to those we present in this paper.
} 
above arguments, we thus establish our sixth and seventh hypotheses as follows:

Hypothesis 6: We expect the favourable effect of the weight of banks on the cost of debt to be attenuated in those countries where the banking system has greater solvency problems.

Hypothesis 7: We expect a more negative effect or a lower positive effect of bank concentration on the cost of debt in those countries where the banking system has greater solvency problems.

\subsection{Economic development}

Levine et al. (2000) and Claessens and Laeven (2003) show that developing countries are characterized by poorer institutions and less information disclosure, which could increase the intensity of information asymmetries. The higher degree of asymmetric information in developing countries can lead to institutions and the banking system playing a more important role in these countries compared to developed countries. We consider the natural logarithm of the country's gross national income per capita (GNI_PC), obtained from the World Bank's database, as an indicator of its degree of economic development and analyse whether laws, institutions, and the banking structure affect the cost of corporate debt differently depending on the level of development of the country. To perform this analysis, we introduce the interaction term between the degree of economic development and each of our main variables, namely the efficiency of the legal system, the protection of creditors' rights, the depth of credit information, the weight of banks in the economy, and bank concentration. The eighth hypothesis is thus as follows:

Hypothesis 8: We expect institutions and the banking system to have a greater influence in countries with a lower degree of economic development.

\section{Data overview}

\subsection{Sample and variables}


The sample used to analyse the cost of debt was obtained from the Worldscope Database and covers the period 2003-2012. This database contains economic-financial and stock market valuation information for over 51,000 firms from 70 countries. Those countries without any information on the institutional and banking structure variables considered in the paper were excluded from the sample. Our analysis thus considers 19,785 non-financial firms from 37 different countries, providing a total of 152,432 observations. The baseline model used to test the hypotheses is the following:

$$
\begin{aligned}
& A D J_{-} C_{C O S T}=\beta_{0}+\beta_{1} L E V_{i t-1}+\beta_{2} E_{\text {EIT }} / I N T_{i t-1}+\beta_{3} M A T_{i t-1}+\beta_{4} P R O F_{i t-1}+ \\
& \beta_{5} T A N G_{i t-1}+\beta_{6} S_{I Z E_{i t-1}}+\beta_{7} M T B_{i t-1}+\beta_{8} I N F_{i t-1}+\beta_{9} R_{-} L A W_{j t}+\beta_{10} L E G_{-} I N D_{j t}+ \\
& \beta_{11} R_{-} L A W * L E G_{-} I N D_{j t}+\beta_{12} D E P_{-} I N F_{j t}+\beta_{13} D E P_{-} I N F * L E G_{-} I N D_{j t}+ \\
& \beta_{14} B_{-} C R E D I T_{j t}+\beta_{15} B_{-} C O N C_{j t}+\varepsilon_{i t}
\end{aligned}
$$

The estimations were carried out using panel data. Prior to testing, we used the Breusch-Pagan test (Breusch and Pagan, 1980) to identify the existence of individual effects. The null hypothesis of no unobserved heterogeneity is rejected. In this context, a model that captures individual heterogeneity, as the panel data methodology does, is appropriate. The panel data methodology corrects for unobserved firm-specific and time-specific effects. The panel data estimation was calculated using fixed effects. To correct for the limited influence of countries with a small number of observations, we use a weighted regression approach that assigns a country-specific weight, which is equal to the inverse number of firms in each country. We consider industry and year effects, including industry-year dummy variables. All independent firm-level variables are lagged by one year to control for potential problems of endogeneity.

The adjusted cost of debt (ADJ_COST) is the dependent variable in our analysis. It is defined as the cost of debt minus the median value of the industry cost of debt (Zou and Adams, 2008). The cost of debt is calculated as the ratio of financial expenses and total debt (Jun and Jen, 2003; Pittman and Fortin, 2004). Financial expenses comprise all those expenses resulting from external financing. Total debt represents all debts with cost and is the sum of short- and long-term debt. 
Total debt is defined considering average debt, which is the average of total debt at the beginning and the end of the period. We winsorized this variable at the top and bottom $1 \%$ of its distribution by country.

\subsubsection{Laws, institutions, and the banking structure}

The institutional variables we consider are the rule of law, the protection of creditors' rights, and the depth of credit information. We also take into account two variables related to banking structure, namely the weight of bank financing and the degree of bank concentration.

Rule of law measures perceptions of the extent to which agents have confidence in and abide by the rules of society; in particular, the quality of contract enforcement, property rights, the police, and the courts, as well as the likelihood of crime and violence. The source from which we extracted the data is the World Bank's WGI database. The values of this indicator range between -2.5 and 2.5: lower values reflect poor rule of law, while higher values reflect a highly efficient legal system. This measurement is similar to those used by Demirgüç-Kunt and Maksimovic (1999) and Bae and Goyal (2009), who respectively used the variables of law and order, and property rights.

To analyse the effect of the protection of creditor rights on the cost of debt, we include the strength of the legal rights index, which measures the degree to which collateral and bankruptcy laws protect the rights of borrowers and lenders and thus facilitate lending. The data are collected from the World Bank's Doing Business database. The index ranges from 0 to 10, with higher scores indicating that these laws are better designed to expand access to credit. The legal rights index includes eights aspects related to legal rights in collateral law and two aspects in bankruptcy law. A score of one is added for each of the following features of the laws: (i) any business may use movable assets as collateral while keeping possession of assets, and any financial institution may accept such assets as collateral; (ii) the law allows a business to grant a non-possessory security right in a single category of revolving movable assets; (iii) the law allows a business to grant a non-possessory security right in substantially all of its assets, without requiring a specific 
description of the secured assets; (iv) a security right may extend to future or after-acquired assets and may extend automatically to the products, proceeds, or replacements of the original assets; (v) general descriptions of debts and obligations are permitted in collateral agreements and in registration documents; (vi) a collateral registry is in operation that is unified geographically and by asset type and that is indexed by the name of the grantor of a security right; (vii) secured creditors are paid first (e.g. before general tax claims and employee claims) when a debtor defaults outside an insolvency procedure; (viii) secured creditors are paid first when a business is liquidated; (ix) secured creditors are not subject to an automatic stay or moratorium on enforcement procedures when a debtor enters a court supervised reorganization procedure; and (x) the law allows parties to agree in a collateral agreement that the lender may enforce its security right of court.

The depth of credit information index measures rules affecting the scope, accessibility, and quality of credit information available through public or private credit registers. The data are also collected from the World Bank's Doing Business database. A value of one is added to the index for each of the following six aspects of a public or private credit registry (or both): (i) both positive credit information (e.g. loan amounts and pattern of on-time repayments) and negative information (e.g. late payments, number and amount of defaults and bankruptcies) are distributed; (ii) data on both firms and individuals are distributed; (iii) data from retailers, trade creditors, and utility firms are distributed to financial institutions; (iv) more than two years of historical data are distributed; (v) data on loans below $1 \%$ of income per capita are distributed; and (vi) regulations are provided to guarantee borrowers the rights to access their data in the largest registry in the economy. The index ranges from 0 to 6 , with higher values indicating the availability of more credit information, from either a public register or a private bureau, to facilitate lending decisions.

We consider two banking structure variables, namely the weight of bank financing and the degree of bank concentration. To measure the weight that banks have in the economy of a country, we use the ratio of private credit by deposit money banks and other financial institutions to GDP, reflecting the weight that financial institutions have in the financing of the firms in a country. The 
data were obtained from the World Bank's Doing Business database.

The second banking structure variable considered in the study is the degree of bank concentration. In line with Demirgüç-Kunt et al. (2004) and Beck et al. (2006), in this paper we define bank concentration as the percentage of assets of the three largest banks as a share of the assets of all commercial banks. The data were obtained from the World Bank's Doing Business database.

A potential problem when considering banking structure proxies is that these variables may themselves be affected by the development of other institutions. We resolve this question regarding the potential endogeneity of our banking structure proxies using instrumental variables estimation. We consider several variables as instruments of the weight of banks in the economy and bank concentration. The proxies are: the sum of short-term and long-term capital flows plus foreign direct investment into the country divided by GDP (Demirgüç-Kunt and Maksimovic, 1999); total population and total GDP (Cetorelli and Gambera, 2001); and entry into banking requirements (Barth et al., 2013). Subsequently, we perform an endogeneity test of overidentifying restrictions for each of the regressions. This test, which verifies the null hypothesis that the specified endogenous regressors can actually be treated as exogenous, is distributed as chi-squared with the degrees of freedom being equal to the number of tested regressors. When the p-value of the F-test is below 10 percent, the null hypothesis is rejected and hence the instrumental variables estimations are reported. Otherwise, the estimations with the observed values of the banking structure variables are provided. Additionally, in order to test the validity of our instruments, we consider the Cragg-Donald statistic, comparing it with the critical values computed by Stock and Yogo (2005). Those cases in which the Cragg-Donald statistic is higher than the Stock and Yogo critical values would indicate the absence of the weak instruments problem.

\subsubsection{Firm variables}

The observed differences in the cost of debt among countries depend partly on the characteristics of the firms in each economy. We accordingly introduce firm-level variables suggested by theory 
which have been used in previous studies analysing the corporate cost of debt (Berger and Udell, 1995; Petersen and Rajan, 1994; Pittman and Fortin, 2004; Zou and Adams, 2008). Table A in the Appendix provides the definition and source of each variable. We winsorize the firm-level variables at the 1st and 99th percentiles by country to lessen the influence of outliers.

Firms with higher levels of leverage (LEV) are more likely to become insolvent in the future; hence, moral hazard problems are more common in these firms. However, a high level of leverage can also be understood as a proxy for the fact that firms have gained a good reputation in the debt markets, which would improve the conditions of the loans. High positive values of the ratio between EBIT and interest expenses (EBIT/INT) indicate that the firm is able to generate sufficient resources to meet its debt commitments, leading to a lower cost of debt. The higher the percentage of long-term debt (MAT) with respect to total debt, the greater the cost of debt will be, given that a greater maturity of the loans is associated with higher risk. Therefore, higher interest rates will be required to offset this increased risk. However, maturity could also be associated with less risk, seeing as larger and longer-term loans generally have lower risk premia, suggesting that larger or longer-term borrowers may be safer (Berger and Udell, 1990). When a firm obtains high economic profitability (PROF), its ability to meet debt commitments will be higher, thereby providing greater assurance to lenders and resulting in a lower cost of debt (Petersen and Rajan, 1994). If most of the assets owned by a firm are tangible (TANG) and the firm has trouble meeting its debt commitments, it can access the market and get cash. This will provide greater guarantees, which will in turn allow it to obtain financing at a lower cost. Smaller firms (SIZE) tend to suffer higher information asymmetry, while larger firms have better access to funding, presenting a lower risk of default, resulting in a lower cost of debt. Higher levels of the market-to-book ratio (MTB) will indicate higher growth opportunities and therefore higher risk, which will accordingly lead to a higher cost of debt. In addition to including the aforementioned variables, we also include the inflation rate (INF). Inflation as measured by the consumer price index reflects the annual percentage change in the cost to the average consumer of acquiring a basket of goods and services that may be fixed or changed at specified intervals, 
such as yearly. The expected result is that the higher the inflation, the higher the cost of debt to provide lenders with real returns adjusted to the level of borrower risk.

\subsubsection{Extended models}

In order to test whether the effect of the banking structure variables on the cost of debt may be affected by the soundness of banks, we introduce a measure of the solvency problems of financial institutions, namely the percentage of bank non-performing loans to total gross loans (NPL). We add the interaction terms B_CREDIT*NPL and B_CONC*NPL, as well as NPL alone, to Equation 1. In this context, the interaction terms B_CREDIT*NPL and B_CONC*NPL measure the differential effect of bank financing and bank concentration, respectively, according to the solvency of the country's banks proxied by the percentage of non-performing loans.

When the degree of economic development is taken into account, we introduce in Equation (1) a proxy of the country's economic development (GNI_PC) and the interaction terms between the measure of economic development and our main variables, namely rule of law, protection of creditors' rights, depth of credit information, and banking structure variables. The interaction terms between the degree of economic development and the main variables of our analysis will measure the differential effect of the institutions and banking structure of the countries when the economic development of the country increases.

\subsection{Descriptive statistics}

Table 1 shows the median values of the dependent variable, the country-level variables, and the firm-level variables, as well as the number of firms and observations for each country. US and Japanese firms comprise approximately $36 \%$ of the sample, while other countries, such as Chile, Ireland, and Portugal contribute only a little to our sample. ${ }^{3}$ A wide variation in the cost of debt

\footnotetext{
${ }^{3}$ The limited influence of some countries in our sample is considered in the analysis using the weighted regression approach. Furthermore, in the robustness analysis we replicate our main estimations without the observations of US and Japan firms in order to check whether or not our results are robust to their inclusion in the sample.
} 
between countries can be observed, the median of the industry-adjusted cost of debt for the total sample being $-0.06 \%$. However, there are countries like Japan, Chile, and Italy whose adjusted cost of debt is negative and below 1\%, and others such as South Africa and Brazil for which it is higher than $5 \%$. These differences could be partly due to the influence of laws, institutions, and the variables related to banking structure, whose values also vary between countries. ${ }^{4}$ Countries such as Finland, Denmark, Norway, and Sweden stand out as having a high rule of law, while others such as Pakistan, Indonesia, Peru, and the Philippines present very low values of this variable. As regards the protection of creditors' rights, countries like Hong Kong, Malaysia, New Zealand, Singapore, South Africa, and the UK show a high level of this variable, whereas the degree of protection in Portugal, Italy, Indonesia, and Brazil is limited. As to the depth of credit information, Austria, the UK, and the USA, among others, have the highest values, while the Philippines and Singapore present the lowest values, although the observed variability among most of the countries is low. The countries in which banks have greater weight in the economy are the USA, Japan, Ireland, and the Netherlands, while Mexico and Peru are the two countries with the lowest weight of banks. Finally, countries like Finland, Norway, and Sweden have a higher degree of bank concentration, while India and the USA comprise those with a lower degree.

\section{[Insert Table 1]}

Table 2 presents the correlation matrix. As forecasted in Hypotheses 1, 2, and 4, ADJ_COST shows a negative correlation with rule of law, protection of creditors' rights, and the weight of banks in the economy. However, we do not observe any significant correlation of the dependent variable with the depth of credit information or bank concentration. As for the firm-level variables, the dependent variable is negatively correlated with tangibility and size, in line with Petersen and Rajan (1994) and Zou and Adams (2008). In general, the correlations between firm-

\footnotetext{
${ }^{4}$ In the robustness analysis, we consider an alternative measure of our dependent variable, which is the cost of debt adjusted by the government five-year bond yield (Borisova et al., 2015) in order to test the robustness of our results according to the definition of the dependent variable.
} 
level variables are low. Additionally, the correlation of the dependent variable with GNI_PC is negative, revealing that the cost of debt is lower in more developed countries. The degree of economic development (GNI_PC) is positively correlated with the rule of law (R_LAW) and the depth of credit information (DEP_INF), in line with Levine et al. (2000), who show that developing countries are characterized by poorer institutions and less informative disclosure. As expected, more developed countries have less inflation (INF) and a higher ratio of private credit by banks to GDP (B_CREDIT) compared to less developed countries. As some of the correlations between the country-level variables are high, such as B_CREDIT and R_LAW, these variables are included both individually and jointly in the estimations.

[Insert Table 2]

\section{Results}

\subsection{Cost of debt, institutions, and banking structure variables}

Table 3 presents the results from the panel data estimation for Equation (1). Column (1) shows the results when the firm-level determinants of the cost of debt and inflation are considered. Columns (2) to (7) provide the results when the country variables are included individually. Column (8) shows the results when all the country variables are considered.

The variable R_LAW has a negative coefficient, indicating that firms in countries with strong legal enforcement have a lower cost of debt. This coefficient is statistically significant, thus confirming our first hypothesis. The level of protection of creditors' rights (LEG_IND) is also seen to have a negative influence on the cost of debt. Firms in countries with strong protection of creditors' rights tend to issue debt at a lower cost, confirming our second hypothesis. These results are in line with those obtained by Qian and Strahan (2007) and Bae and Goyal (2009).

\section{[Insert Table 3]}

We also include the interaction term between rule of law and protection of creditors' rights to test the joint effect of these two variables empirically. The results show that both strong legal 
enforcement and a high level of protection of lenders and borrowers' rights reduce the cost of debt. However, the joint presence of both variables decreases this reduction, indicating that the rule of law and creditor protection variables act as substitutes in reducing the cost of debt. Therefore, both legal enforcement and the protection of creditors' rights could be said to be alternative mechanisms to reduce the cost of debt. To aid the interpretation of our results, we have calculated standardized coefficients. Our results are economically significant. For example, in terms of economic significance, the reported coefficients in column (8) suggest that a onestandard-deviation increase in R_LAW or in LEG_IND is associated with a reduction in the standard deviation of the cost of debt of $4.92 \% \%^{5}$ and $4.60 \%$, respectively.

Surprisingly, the depth of credit information (DEP_INF) is seen to have a positive influence on the cost of debt, ${ }^{6}$ although the effect is not statistically significant in column (5). We have also included the interaction term between the depth of credit information and creditors' rights. However, this effect is not statistically significant in our analysis, suggesting the absence of a joint effect of these two variables on the cost of debt.

As far as the banking structure variables are concerned, the weight of banks in the economy (B_CREDIT) is seen to have a negative influence on the cost of debt. ${ }^{7}$ The increased participation of financial institutions in the economy, coupled with their role in reducing information asymmetries and agency costs, means better expertise and an enhanced capacity to evaluate the

\footnotetext{
${ }^{5}$ The economic effect of R_LAW on the standard deviation of the cost of debt has been calculated as follows: $\left[\left(\beta_{9}+\beta_{11} *\right.\right.$ LEG_IND)* $\left.\sigma_{-}\left(\mathrm{R} \_L A W\right)\right] / \sigma_{-}($ADJ_COST) [see Equation 1$]$. As the mean value of LEGAL_IND for the observations included in the estimation (column (8) in Table 3) is 7.624, the standard deviation of R_LAW is 0.692, and the standard deviation of ADJ_COST is 0.289. Substituting these values in the above expression and the values of the coefficients for R_LAW $\left(\beta_{9}\right)$ and R_LAW*LEG_IND $\left(\beta_{11}\right)$, gives a value of the economic effect of R_LAW of 4.92\%. The effect of LEG_IND on the standard deviation of the cost of debt has been calculated in a similar way.

${ }^{6}$ DEPTH_INF shows little variability among countries and among years and this issue could be affecting the results obtained in the paper. To address this issue, we have considered other measures of the availability of credit information, such as credit registry coverage and credit bureau coverage (Djankov et al. 2007; Sorge et al., 2017) and the Score-Depth of the credit information index. Both measures were obtained from the World Bank's Doing Business database. The results obtained using these two alternatives to measure the depth of credit information do not improve the results when DEP_INF is used, as these variables are not significant in explaining the dependent variable, or even have the opposite sign to the expected one.

${ }^{7}$ The effect of B_CREDIT is not statistically significant in column (6). The different effect of this variable in columns (6) and (8) could be due to the correlation between B_CREDIT and R_LAW.
} 
quality of borrowers' projects, thus leading to a reduction in default risk, given that these institutions have more information on borrowers. As a result of assuming less risk of default, they will be able to offer better credit conditions. Hence, we can confirm our fourth hypothesis, which posits that a higher weight of bank financing reduces the cost of debt. The cost of debt is likewise seen to increase in countries in which bank concentration (B_CONC) is high. This finding suggests that an increase in bank concentration leads to a higher cost of debt, a result in line with Hypothesis 5a. The results are economically significant. A one-standard-deviation increase in B_CREDIT results, on average, in a $19.20 \%$ reduction in the standard deviation of the cost of debt, while a one-standard-deviation increase in B_CONC results, on average, in a $2.71 \%$ increase in the standard deviation of the cost of debt.

The effect of the banking structure variables on the cost of debt could be affected by the solvency problems of financial institutions. In column (9), we include the percentage of bank nonperforming loans to total gross loan (NPL) as a proxy for the solvency of financial institutions, considering that the higher the percentage of non-performing loans, the greater the solvency problems of financial institutions in a country. Legal enforcement and the protection of creditors' rights reduce the cost of debt, while the depth of credit information is not significant. As for the effect of the banking structure variables, the negative relationship between the weight of banks and the cost of debt is attenuated when the solvency of the country's banks is more affected, as the effect of the interaction term is lower in absolute value than the coefficient of B_CREDIT. Hence, we can confirm our sixth hypothesis related to the favourable effect of the weight of banks on the cost of debt being attenuated in those countries where the banking system has higher solvency problems.

As for bank concentration, our results show that the positive effect of bank concentration on the cost of debt is statistically significant only when the financial problems of banks are greater, as the coefficient of B_CONC is not significant. These results indicate that banks take advantage of their market power in those cases in which they have greater solvency problems. Therefore, our seventh hypothesis, which posits that we could expect a more positive effect of bank 
concentration on the cost of debt if banks have greater solvency problems, is confirmed. The main term of the non-performing loans variable is negative and significant. To aid the interpretation of this result, we have calculated the economic effect considering not just the main term of NPL, but also the interaction terms with B_CREDIT and B_CONC. In terms of economic significance, the reported coefficient in column (9) suggests that a one-standard-deviation increase in NPL is associated with a $0.34 \%$ increase in the standard deviation of the cost of debt.

Analysis of the results for the firm control variables shows that the cost of debt is negatively related to leverage (LEV). This is consistent with the idea that the level of leverage reflects the good reputation that companies have acquired in the debt markets, thus allowing a reduction in the cost of debt. Maturity (MAT) has a negative influence on the cost of debt, a result in keeping with longer-term loans being safer. The profitability variable (PROF) shows a negative and statistically significant coefficient. This result suggests that high economic profitability provides greater assurance to lenders. The SIZE variable has a negative and significant influence on the cost of debt, reflecting the fact that larger firms have better access to external financing. The market-to-book ratio (MTB) has a positive and significant effect on the cost of debt, reflecting that firms with higher growth opportunities are riskier. As a consequence of this higher level of risk, the cost of debt is also higher. Inflation (INF) has a positive and significant influence on the cost of debt, indicating that in those countries where inflation is higher, lenders demand higher interest rates, which will allow the generation of real returns adjusted to the level of borrower risk. The EBIT/interest variable (EBIT/INT) and tangibility (TANG) are found to have a positive and negative influence on the cost of debt, respectively, although their effects are not statistically significant in most of the estimations.

Due to the relevance of corporate financial constraints in explaining the cost of debt, we estimated our main regression (column (8) in Table 3) for both financially constrained and unconstrained firms. Following Lamont et al. (2001), we first construct an index of the likelihood that a firm faces financial constraints, namely the Kaplan and Zingales index (K-Z index). Firms in the bottom (top) tertile of the $\mathrm{K}-\mathrm{Z}$ index ranking are considered financially unconstrained 
(constrained). We allow firms to change their status over our sample period by ranking firms on an annual basis. The results (not reported) reveal that country variables affect the cost of debt for financially constrained and unconstrained firms similarly.

\subsection{Economic development, cost of debt, institutions, and banking structure variables}

Table 4 presents the results showing the effect that the variables for institutions and banking structure have on the cost of corporate debt considering the degree of economic development. Column (1) shows the results when considering firm-level determinants of the cost of debt, inflation, and the degree of economic development. Columns (2) to (6) consider the results when the country variables are included individually and jointly with the proxy for economic development. Column (7) show the results when all the variables are included. It can be seen in column (7) that the degree of rule of law, the level of protection of lenders and borrowers' rights, and the weight of banks in the economy reduce the cost of debt when the degree of economic development is not taken into account, although this reduction decreases as the degree of economic development of a country increases. As for the depth of credit information, although this variable has a positive influence on the cost of debt when the degree of economic development is not taken into account,${ }^{8}$ this positive effect is attenuated when there exists a higher level of economic development. The coefficients associated with B_CONC are not statistically significant. Therefore, our seventh hypothesis is confirmed for the rule of law, creditor rights, and the weight of banks in the economy, insofar as these variables reduce the cost of debt to a greater extent in those countries with a lower degree of economic development.

[Insert Table 4]

\footnotetext{
${ }^{8}$ As previously stated, the proxy for depth credit information has limited variability. Moreover, the correlation between DEP_INF and GNI_PC is high. These issues may explain the positive and significant effect of DEP_INF obtained in Table 4.
} 
In terms of economic significance, the coefficients reported in column (7) suggest that, in those countries where the degree of economic development is low, ${ }^{9}$ a one-standard-deviation increase in R_LAW or in LEG_IND is associated with a reduction in the standard deviation of the cost of debt of $17.87 \%$ and $44.21 \%$, respectively. However, these effects are attenuated when the degree of economic development is high, such that a one-standard-deviation increase in R_LAW or in LEG_IND is associated with a reduction in the standard deviation of the cost of debt of $5.88 \%$ and $15.40 \%$, respectively. In those countries with a low degree of economic development, a onestandard-deviation increase in B_CREDIT results, on average, in a 9.15\% reduction in the standard deviation of the cost of debt, while in those countries with a high degree of economic development, the reduction is $3.87 \%$. As to the depth of credit information, in those countries where the degree of economic development is low, a one-standard-deviation increase in DEP_INF is associated with a $0.70 \%$ increase in the standard deviation of the cost of debt. However, in those countries with a high degree of economic development, a one-standard-deviation in DEP_INF is associated with a $0.9 \%$ decrease in the standard deviation of the cost of debt. Both effects are close to zero; hence the effect of the depth of credit information is very low when the degree of economic development is taken into account. ${ }^{10}$

\subsection{Robustness analysis}

This section provides additional robustness tests for our results. First, we consider an additional measure of the cost of debt, namely the cost of debt adjusted by the government five-year bond yield (Borisova et al., 2015). Columns (1) and (2) in Table 5 are the main regressions of our analysis, while columns (3) and (4) replicate these estimations with the alternative proxy for the dependent variable. The results are robust irrespective of the way in which we proxy the cost of debt, as they show that the rule of law, the protection of creditors' rights, and the weight of banks

\footnotetext{
${ }^{9}$ We consider the $25^{\text {th }}$ percentile of the distribution to be a country with a low degree of economic development, and the $75^{\text {th }}$ percentile of the distribution to be a country with a high degree of economic development.

${ }^{10}$ The results obtained in Table 3 for DEP_INF and B_CONC are not maintained in Table 4. The proxies for depth of credit information and bank concentration have limited variability, which could explain these differences in the results. Thus, we opt for being cautious in the interpretation of these results.
} 
in the economy have a negative and significant effect on the cost of debt. The results also reveal that the weight of bank financing and bank concentration have a positive differential effect on the cost of debt in those countries where the solvency of banks is lower, as previously shown in Table 3 (column (9)). ${ }^{11}$ As regards the degree of economic development, our results are also robust, as they show that the rule of law, the protection of creditors' rights, and the weight of banks in the economy reduce the cost of debt more in those countries with a lower degree of economic development.

\section{[Insert Table 5]}

Second, in order to test whether our results were driven by US and Japanese firms, which dominate the sample under study, we estimate the results of Table 3 excluding US and Japanese firms. Columns (1) and (2) in Table 6 show the results for the complete sample, columns (3) and (4) for the subsample without Japanese firms, and columns (5) and (6) for the subsample without US firms. The results reveal that there are differences in the sign or significance of the DEP_INF and B_CONC coefficients when US or Japanese firms are excluded from the sample. The coefficient of DEP_INF is negative and significant in columns (4) and (6), suggesting that greater depth of credit information is associated with a lower cost of debt. Thus, the incorrect sign obtained for DEP_INF for the whole sample seems to be due to the inclusion of these countries, as they present high values of DEP_INF and GNI_PC. However, the economic effect of DEP_INF always remains positive, although its effect is low. The measure of bank concentration has a clearly positive effect on the cost of debt when US firms are excluded from the sample, as the USA has one of the lowest values of bank concentration. The effects of the remaining variables on the cost of debt are robust regardless of whether US and Japanese firms are included or not,

\footnotetext{
${ }^{11}$ The only coefficient that is different in terms of significance when we consider the alternative measure of the dependent variable is the one for the DEP_INF*LEG_IND variable, which is positive and significant for the government 5-year bond yield-adjusted cost of debt and non-significant for the industry-median adjusted cost of debt.
} 
although Japanese firms show the lowest value of the dependent variable and US and Japanese firms present higher levels of B_CREDIT.

[Insert Table 6]

\section{Conclusions}

In this paper, we test how the differences in institutions and banking system affect the cost of corporate debt as some countries have stronger institutions and a more efficient banking system structure than other countries. Specifically, we analyse the effect of legal enforcement and the protection of creditors' rights, as well as the effect of the depth of credit information and the structure of the banking system. Furthermore, we take into account bank soundness and the degree of economic development. We examine these aspects employing a sample of firms from 37 countries for the period 2001-2012.

Our results support the view that greater legal enforcement and protection of creditors' rights reduce the cost of corporate debt. These results are in line with those reported by Qian and Strahan (2007) and Bae and Goyal (2009), as they show that protection of investors' rights results in more efficient contracting. Additionally, we find that these two variables are alternative mechanisms for reducing the cost of debt. We also obtain evidence related to the way in which the structure of the banking system affects the cost of debt. A higher weight of banks in the economy tends to reduce the cost of corporate debt, while bank concentration is associated with higher costs for firms. However, both bank concentration and the weight of bank financing have a positive differential effect on the cost of debt when the financial difficulties of banks are greater. These results reveal that banks take advantage of corporate dependence on bank financing and their market power in those cases in which they have been affected by solvency difficulties. The results also show that the effect of institutions and the structure of the banking system are economic development dependent, as legal enforcement, the protection of creditors' rights, and the weight of banks in the economy play a more important role in developing countries than in developed 
countries, reducing the corporate cost of debt to a greater extent in less developed countries in line with the existence of more information asymmetries in these countries.

The results have important implications, as they suggest institutional and banking structure designs that have cost-lowering effects on corporate debt, revealing that such designs may exert a different influence depending on the degree of economic development of the country and the existence of bank solvency problems. Hence, regulators should bear in mind these externalities for corporate cost of debt when adopting decisions regarding the design of the country's institutions or should adopt policies aimed at supporting the financial sector. 


\section{Appendix}

Table A. Variable definitions

\begin{tabular}{|c|c|c|}
\hline VARIABLE & DESCRIPTION & DATA SOURCE \\
\hline \multicolumn{3}{|l|}{ Dependent variables } \\
\hline $\begin{array}{l}\text { Industry-median } \\
\text { adjusted cost of debt } \\
(\text { ADJ_COST) }\end{array}$ & $\begin{array}{l}\text { The cost of debt (ratio between financial expenses and total debt) adjusted } \\
\text { by the median value for the industry. }\end{array}$ & $\begin{array}{l}\text { Worldscope } \\
\text { Database }\end{array}$ \\
\hline $\begin{array}{l}\text { Government } 5 y \text { bond } \\
\text { yield-adjusted cost of } \\
\text { debt }\end{array}$ & The cost of debt adjusted by the government 5 -year bond yield & $\begin{array}{l}\text { Worldscope } \\
\text { Database and } \\
\text { Thomson Reuters }\end{array}$ \\
\hline \multicolumn{3}{|l|}{ Main variables } \\
\hline Rule of law $\left(R_{-} L A W\right)$ & $\begin{array}{l}\text { The perceptions of the extent to which agents have confidence in and abide } \\
\text { by the rules of society, and in particular the quality of contract enforcement, } \\
\text { property rights, the police, and the courts, as well as the likelihood of crime } \\
\text { and violence. The index ranges between }-2.5 \text { (poor legal system) and } 2.5 \\
\text { (efficient legal system). }\end{array}$ & $\begin{array}{l}\text { The World Bank } \\
\text { WGI database }\end{array}$ \\
\hline $\begin{array}{l}\text { Strength of the legal } \\
\text { rights index (LEG_IND) }\end{array}$ & $\begin{array}{l}\text { The degree to which collateral and bankruptcy laws protect the rights of } \\
\text { borrowers and lenders and thus facilitate lending. The index ranges from } 0 \\
\text { to } 10 \text {, with higher scores indicating that these laws are better designed to } \\
\text { expand access to credit. }\end{array}$ & $\begin{array}{l}\text { The World Bank } \\
\text { Doing Business } \\
\text { database }\end{array}$ \\
\hline $\begin{array}{l}\text { Depth of credit } \\
\text { information index } \\
\left(D E P \_I N F\right)\end{array}$ & $\begin{array}{l}\text { An index that measures rules affecting the scope, accessibility, and quality } \\
\text { of credit information available through public or private credit registers. The } \\
\text { index ranges from } 0 \text { to } 6 \text {, with higher values indicating the availability of } \\
\text { more credit information, from either a public register or a private bureau, to } \\
\text { facilitate lending decisions. }\end{array}$ & $\begin{array}{l}\text { The World Bank } \\
\text { Doing Business } \\
\text { Database }\end{array}$ \\
\hline $\begin{array}{l}\text { Weight of banks in the } \\
\text { economy }\left(B \_C R E D I T\right)\end{array}$ & $\begin{array}{l}\text { The ratio of private credit by deposit money banks and other financial } \\
\text { institutions to GDP, reflecting the weight that financial institutions have in } \\
\text { the economy of a country. }\end{array}$ & $\begin{array}{l}\text { The World Bank } \\
\text { Financial Structure } \\
\text { database }\end{array}$ \\
\hline $\begin{array}{l}\text { Degree of bank } \\
\text { concentration } \\
\left(B \_C O N C\right)\end{array}$ & $\begin{array}{l}\text { The percentage of assets of the three largest banks as a share of the assets of } \\
\text { all commercial banks. }\end{array}$ & $\begin{array}{l}\text { The World Bank } \\
\text { Financial Structure } \\
\text { Database }\end{array}$ \\
\hline $\begin{array}{l}\text { Nonperforming loans } \\
(N P L)\end{array}$ & The percentage of bank non-performing loans to total gross loans. & $\begin{array}{l}\text { The World Bank } \\
\text { database }\end{array}$ \\
\hline $\begin{array}{l}\text { Degree of economic } \\
\text { development }\left(G N I \_P C\right)\end{array}$ & The natural logarithm of the variable Gross National Income per capita. & $\begin{array}{l}\text { The World Bank } \\
\text { Database }\end{array}$ \\
\hline \multicolumn{3}{|l|}{ Control variables } \\
\hline Leverage (LEV) & The ratio between total debt and total assets. & $\begin{array}{l}\text { Worldscope } \\
\text { Database }\end{array}$ \\
\hline $\begin{array}{l}\text { EBIT/interest ratio } \\
(\text { EBIT/INT) }\end{array}$ & The ratio between earnings before interest and taxes (EBIT) and interest. & $\begin{array}{l}\text { Worldscope } \\
\text { Database }\end{array}$ \\
\hline Maturity (MAT) & The ratio of long-term debt and total debt. & $\begin{array}{l}\text { Worldscope } \\
\text { Database }\end{array}$ \\
\hline Profitability (PROF) & The ratio of earnings before interest and taxes (EBIT) to total assets. & $\begin{array}{l}\text { Worldscope } \\
\text { Database }\end{array}$ \\
\hline $\begin{array}{l}\text { Tangibility of assets } \\
(T A N G)\end{array}$ & The ratio of tangible fixed assets to total assets. & $\begin{array}{l}\text { Worldscope } \\
\text { Database }\end{array}$ \\
\hline
\end{tabular}




\begin{tabular}{lll}
\hline $\begin{array}{l}\text { Firm size (SIZE) } \\
\text { Market-to-book ratio }\end{array}$ & $\begin{array}{l}\text { The natural logarithm of sales (thousands). } \\
\text { The ratio of the market value of equity plus the book value of total assets } \\
\text { minus the book value of equity to the book value of total assets. }\end{array}$ & $\begin{array}{l}\text { Worldscope } \\
\text { Database }\end{array}$ \\
$\begin{array}{ll}\text { Inflation rate }(I N F) \\
\text { Inflation as measured by the consumer price index reflects the annual } \\
\text { percentage change in the cost to the average consumer of acquiring a basket } \\
\text { of goods and services that may be fixed or changed at specified intervals, } \\
\text { such as yearly. }\end{array}$ & The \\
\hline
\end{tabular}

Proxies for the weight of

banks in the economy

and bank concentration

Inflow The sum of foreign direct investment plus the ratio between portfolio equity and GDP per capita.

Total population Total population is based on the de facto definition of population, which counts all residents regardless of legal status or citizenship, except for refugees not permanently settled in the country of asylum, who are generally considered part of the population of their country of origin. The values shown are midyear estimates.

Total GDP (Constant 2005 US\$)

Entry into banking requirements
GDP at purchaser's prices comprises the sum of gross value added by all resident producers in the economy plus any product taxes and minus any subsidies not included in the value of the products. It is calculated without making deductions for depreciation of fabricated assets or for depletion and degradation of natural resources. Data are in constant 2005 US dollars. Dollar figures for GDP are converted from domestic currencies using 2000 official exchange rates. For a few countries where the official exchange rate does not reflect the rate effectively applied to actual foreign exchange transactions, an alternative conversion factor is used.

An index measuring whether various types of legal submissions are required to obtain a banking license. The index ranges from 0 to 8 , with higher values indicating greater stringency.
The World Bank database

The World Bank database

The World Bank database 


\section{References}

Allen, F., A. Hryckiewicz, O. Kowalewski, and G. Tümer-AlkaneaImperial, 2014, Transmission of financial shocks in loan and deposit markets: Role of interbank borrowing and market monitoring, Journal of Financial Stability 15, 112-126.

Almeida, H., M. Campello, B. Laranjeira, and S. Weisbenner, 2011, Corporate debt maturity and the real effects of the 2007 credit crisis, Critical Finance Review 1, 3-58.

Bae, K., and V. Goyal, 2009, Creditor rights, enforcement, and bank loans, The Journal of Finance 64, 823-860.

Barath, S.T., S. Dahiya, A. Saunders, and A. Srinivsan, 2011, Lending relationships and loan contract terms, Review of Financial Studies 24, 1141-1203.

Barth, J.R., G.J. Caprio, and R. Levine, 2004, Bank regulation and supervision: What works best?, Journal of Financial Intermediation 13, 205-248.

Barth, J. R., G.J. Caprio, and R. Levine, 2013, Bank Regulation and Supervision in 180 Countries from 1999 to 2011, Working paper (National Bureau of Economic Research).

Beck, T., A. Demirgüç-Kunt, and R. Levine, 2006, Bank concentration, competition, and crises: First results, Journal of Banking \& Finance 30, 1581-1603.

Berger, A.N., and G.F. Udell, 1990, Collateral, loan quality and bank risk, Journal of Monetary Economics 25, 21-42.

Berger, A., and G. Udell, 1995, Relationship lending and lines of credit in small firm finance, Journal of Business 68, 351-379.

Boot, A.W.A., 2000, Relationship banking: What do we know? Journal of Financial Intermediation 9, 7-25. 
Borisova, G., V. Fotak, K. Holland, and W.L. Megginson, 2015, Government ownership and the cost of debt: Evidence from government investments in publicly traded firms, Journal of Financial Economics 118, 168-191.

Breusch, T., and A. Pagan, 1980, The Lagrange multiplier test and its applications to model specification in econometrics, The Review of Economic Studies 47, 239-253.

Brown, M., T. Japelli, and M. Pagano, 2009, Information sharing and credit: firm-level evidence from transition countries, Journal of Financial Intermediation 18, 151-172.

Bruha, J., and E. Kocenda, 2018, Financial stability in Europe: Banking and sovereign risk, Journal of Financial Stability 36, 305-321.

Campello, M., J.R. Graham, and C.R. Harvey, 2010, The real effects of financial constraints: Evidence from a financial crisis, Journal of Financial Economics 97, 470-487.

Cetorelli, N., and M. Gambera, 2001, Banking market structure, financial dependence and growth: International evidence from industry data, The Journal of Finance 56, 617-648.

Chen, H., Y. Liao, C. Lin, and J. Yen, 2018, The effect of the political connections of government bank CEOs on bank performance during the financial crisis, Journal of Financial Stability 36, $130-143$.

Cihák, M., and K. Schaeck, 2010, How well do aggregate prudential ratios identify banking system problems?, Journal of Financial Stability 6, 130-144.

Claessens, S., and L. Laeven, 2003, Financial Development, property rights, and growth, The Journal of Finance 58, 2401-2436.

Cubillas, E., A.I. Fernández, and F. González, 2017, How credible is a too-big-to-fail policy? International evidence from market discipline, Journal of Financial Intermediation 29, 46-67.

De Jong, A., R. Kabir, and T.T. Nguyen, 2008, Capital structure around the world: The roles of 
firm- and country-specific determinants, Journal of Banking and Finance 32, 1954-1969.

Dell'Ariccia, G., E. Detragiache, and R. Rajan, 2008, The real effect of banking crises, Journal of Financial Intermediation 17, 89-112.

Dell'Ariccia, G., and R. Marquez, 2004, Information and bank credit allocation, Journal of Financial Economics 72, 185-214.

Demirgüç-Kunt, A., and V. Maksimovic, 1999, Institutions, financial markets, and firm debt maturity, Journal of Finance Economics 54, 295-336.

Demirgüç-Kunt, A., L. Laeven, and R. Levine, 2004, Regulations, market structure, institutions, and the cost of financial intermediation, Journal of Money, Credit and Banking 36, 593-622.

Diamond, D. W., 1984, Financial intermediation and delegated monitoring, Review of Economic Studies 51, 393-414.

Djankov, S., M. Caralee and S. Andrei, 2007, Private Credit in 129 countries?, Journal of Financial Economics 84, 299-329.

Duchin, R., O. Ozbas, and B. Sensoy, 2010, Costly external finance, corporate investment, and the subprime mortgage crisis, Journal of Financial Economics 97, 418-435.

Espenlaub, S., A. Khurshed, and T. Sitthipongpanich, 2012, Bank connections, corporate investment and crisis, Journal of Banking and Finance 36, 1336-1353.

Fama, E., 1985, What's different about Banks? Journal of Monetary Economics 15, 29-39.

Fan, H. J., S. Titman, and G. Twite, 2012, An international comparison of capital structure and debt maturity choices, Journal of Finance and Quantitative Analysis 47, 23-56.

Gaud, P., E. Jani, M. Hoesli, and A. Bender, 2005, The capital structure of Swiss companies: An empirical analysis using dynamic panel data, European Financial Management 11, 51-69. 
Giannetti, M., 2003, Do better institutions mitigate agency problems? Evidence from corporate finance choices, Journal of Finance and Quantitative Analysis 38, 185- 212.

González, F., 2005, Bank regulation and risk-taking incentives: An international comparison of bank risk, Journal of Banking and Finance 29, 1153-1184.

González, V. M., and F. González, 2008, Influence of bank concentration and institutions on capital structure: New international evidence, Journal of Corporate Finance 14, 363-375.

González, V.M., 2015, The financial crisis and corporate debt maturity: The role of banking structure, Journal of Corporate Finance 35, 310-328.

González, V.M., 2017, Firm and country determinants of debt maturity. New international evidence, International Finance 20, 256-270.

Gungoraydinoglu, A., G. Çolak, and Ö. Öztekin, 2017, Political environment, financial intermediation costs, and financing patterns, Journal of Corporate Finance 44, 167-192.

Ivashina, V., and D. Scharfstein, 2010, Bank lending during the financial crisis of 2008, Journal of Financial Economics 97, 319-338.

Jimenez, G., J.A. López, and J. Saurina, 2013. How does competition affect bank risk-taking?, Journal of Financial Stability 9, 185-195.

Jun, S., and F. Jen, 2003, Trade-off model of debt maturity structure, Review of Quantitative Finance and Accounting 20, 5-34.

Laeven, L., and R. Levine, 2009, Bank governance, regulation and risk taking, Journal of Financial Economics 93, 259-275.

Laeven, L., and F. Valencia, 2012, Systemic banking crises database: An update prepared by Luc Laeven and Fabian Valencia, Working paper (International Monetary Fund). 
Lamont, O., C. Polk, and J. Sáa-Requejo, 2001, Financial constraints and stock returns, The Review of Financial Studies 14, 529-554.

Levine, R., N. Loayza, and T. Beck, 2000, Financial intermediation and growth: Causality and causes, Journal of Monetary Economics 46, 31-77.

Öztekin, Ö., and M. Flannery, 2012, Institutional determinants of capital structure adjustment speeds, Journal of Financial Economics 103, 88-112.

Padilla, A. J., and M. Pagano, 2000, Sharing default information as a borrower discipline device, European Economic Review 44, 1951-1980.

Pagano, M., and T. Japelli, 1993, Information sharing in credit markets, The Journal of Finance $48,1693-1718$.

Petersen, M., and R. Rajan, 1994, The benefits of lending relationships: Evidence from small business data, The Journal of Finance 49, 3-37.

Petersen, M., and R. Rajan, 1995, The effect of credit market competition on lending relationships, Quarterly Journal of Economics 110, 407-443.

Pittman, J., and S. Fortin, 2004, Auditor choice and the cost of debt capital for newly public firms, Journal of Accounting and Economics 37, 113-136.

Qian, J., and P. Strahan, 2007, How laws and institutions shape financial contracts: The case of bank loans, The Journal of Finance 62, 2803-2834.

Qian, X., T. Cao, and C. Cao, 2018, Institutional environment and bank loans: Evidence from 25 developing countries, Corporate Governance: An International Review 26, 84-96.

Rajan, R.G., 1992, Insiders and Outsiders: The Choice Between Informed and Arm's Length Debt, The Journal of Finance 47, 1367-1400. 
Santos, J.A.C., and A. Winton, 2008, Bank Loans, Bonds, and Information Monopolies across the Business Cycle, The Journal of Finance 63, 1315-1359.

Santos, J.A.C., 2011, Bank corporate loan pricing following the Subprime Crisis, The Review of Financial Studies 24, 1916-1943.

Sorge, M., C. Zhang, and K. Koufopoulos, 2017, Short-term corporate debt around the world, Journal of Money, Credit and Banking 49, 997-1029.

Stock, J. H., and M. Yogo, 2005, Testing for weak instruments in linear IV regressions, in: Andrews, D.W.K., ed., Identification and Inference for Econometric Models, Cambridge University Press, 80-108.

Stojanovic, D., M.D. Vaughan, and T.J. Yeager, 2008, Do Federal Home Loan Bank membership and advances increase bank risk-taking?, Journal of Banking and Finance 32, 680-698.

Zou, H., and M. Adams, 2008, Debt capacity cost of debt, and corporate insurance, Journal of Financial and Quantitative Analysis 43, 433-466. 
Table 1. Descriptive statistics by country.

This table reports the median values of the dependent variable, country-level variables, and firm-level variables for each country. FREQ measures the observation distribution (in percentage). OBS is the number of observations. FIRMS is the number of firms. ADJ_COST is the industry-median adjusted cost of debt (in percentage). R_LAW is one of the six dimensions of the WGI and is a measure of the efficiency of the legal system. LEG IND measures the protection of borrowers and lenders' rights. DEP INF measures the depth of credit information. B CREDIT is the ratio of private credit by deposit money banks to GDP. B CONC is the fraction of assets held by the three largest commercial banks in each country. NPL measures bank non-performing loans to total gross loans (\%). GNI PC is the natural logarithm of Gross National Income per capita. LEV is the ratio between total debt and total assets (in percentage). EBIT/INT is the ratio between earnings before interest and taxes and interest. MAT is the ratio between long-term debt and total debt (in percentage). PROF is the ratio between EBIT and total assets (in percentage). TANG is the ratio between tangible fixed assets and total assets (in percentage). SIZE is the natural logarithm of sales (thousands). MTB is the market value of equity plus the book value of total assets minus the book value of equity, all divided by the book value of total assets. INF is the rate of inflation (in percentage).

\begin{tabular}{|c|c|c|c|c|c|c|c|c|c|c|c|c|c|c|c|c|c|c|c|}
\hline Country & FREQ & OBS & FIRMS & ADJ_COST & R_LAW & LEG_IND & DEP_INF & B_CREDIT & B_CONC & NPL & GNI_PC & LEV & EBIT/INT & MAT & PROF & TANG & SIZE & MTB & INF \\
\hline Australia & 3.23 & 4,931 & 756 & 2.62 & 1.75 & 9.00 & 5.00 & 1.10 & 0.68 & 1.26 & 10.65 & 21.44 & 2.43 & 67.13 & 5.20 & 25.01 & 3.80 & 1.31 & 2.84 \\
\hline Austria & 0.34 & 524 & 57 & 0.00 & 1.86 & 7.00 & 6.00 & 1.12 & 0.62 & 2.71 & 10.79 & 23.79 & 5.29 & 58.54 & 6.64 & 35.78 & 5.83 & 1.16 & 2.06 \\
\hline Belgium & 0.52 & 798 & 92 & 0.03 & 1.33 & 6.00 & 4.00 & 0.84 & 0.85 & 2.60 & 10.74 & 25.04 & 3.76 & 64.59 & 5.89 & 24.41 & 5.57 & 1.16 & 2.09 \\
\hline Brazil & 1.37 & 2,083 & 243 & 8.41 & -0.30 & 3.00 & 5.00 & 0.42 & 0.51 & 3.46 & 8.90 & 28.57 & 1.86 & 57.98 & 9.76 & 36.85 & 5.81 & 1.18 & 5.66 \\
\hline Canada & 3.86 & 5,884 & 939 & 1.19 & 1.79 & 7.00 & 6.00 & 1.64 & 0.63 & 0.76 & 10.67 & 24.22 & 1.56 & 72.62 & 3.44 & 41.85 & 4.11 & 1.40 & 2.14 \\
\hline Chile & 0.14 & 216 & 108 & -1.46 & 1.37 & 6.00 & 5.00 & 0.80 & & 2.16 & 9.57 & 25.83 & 6.26 & 77.34 & 7.27 & 43.35 & 5.79 & 1.25 & 3.34 \\
\hline Denmark & 0.58 & 889 & 99 & 0.08 & 1.93 & 9.00 & 4.00 & 1.62 & 0.82 & 1.20 & 11.00 & 24.75 & 3.48 & 61.64 & 5.50 & 28.92 & 5.11 & 1.17 & 2.09 \\
\hline Finland & 0.62 & 941 & 108 & -0.40 & 1.96 & 8.00 & 4.00 & 0.75 & 0.99 & 0.50 & 10.74 & 24.80 & 5.33 & 67.79 & 7.43 & 21.79 & 5.38 & 1.32 & 1.57 \\
\hline France & 3.19 & 4,862 & 565 & -0.85 & 1.43 & 7.00 & 4.00 & 0.99 & 0.62 & 4.02 & 10.67 & 20.59 & 4.81 & 60.94 & 5.59 & 12.12 & 5.06 & 1.21 & 1.73 \\
\hline Germany & 2.94 & 4,478 & 551 & 1.49 & 1.64 & 7.00 & 6.00 & 1.09 & 0.73 & 3.31 & 10.61 & 21.49 & 3.13 & 62.88 & 5.52 & 21.68 & 5.11 & 1.18 & 1.58 \\
\hline Greece & 1.41 & 2,144 & 236 & 0.08 & 0.77 & 4.00 & 4.00 & 0.86 & 0.66 & 7.00 & 10.13 & 33.26 & 2.17 & 41.96 & 4.00 & 36.08 & 4.43 & 1.02 & 3.38 \\
\hline Hong Kong & 4.43 & 6,747 & 809 & 0.56 & 1.53 & 10.00 & 5.00 & 1.42 & 0.73 & 1.23 & - & 19.31 & 3.96 & 34.54 & 4.21 & 22.42 & 4.46 & 1.04 & 0.89 \\
\hline India & 7.88 & 12,017 & 1,936 & 2.65 & 0.02 & 8.00 & 5.00 & 0.45 & 0.30 & 2.67 & 7.05 & 33.21 & 3.19 & 60.64 & 8.85 & 37.87 & 4.02 & 1.08 & 8.35 \\
\hline Indonesia & 1.48 & 2,260 & 282 & 1.93 & -0.66 & 3.00 & 4.00 & 0.23 & 0.45 & 3.29 & 7.57 & 31.45 & 2.75 & 44.71 & 6.94 & 39.33 & 4.44 & 1.07 & 6.41 \\
\hline Ireland & 0.18 & 273 & 36 & 0.46 & 1.71 & 9.00 & 5.00 & 1.86 & 0.71 & 1.92 & 10.69 & 29.09 & 3.93 & 84.85 & 6.31 & 26.34 & 6.87 & 1.39 & 3.48 \\
\hline Israel & 1.19 & 1,812 & 285 & 0.82 & 0.89 & 9.00 & 5.00 & 0.91 & 0.77 & 2.40 & 10.21 & 32.47 & 2.52 & 54.44 & 5.79 & 17.62 & 4.28 & 1.11 & 2.69 \\
\hline Italy & 1.17 & 1,778 & 206 & -1.25 & 0.42 & 3.00 & 5.00 & 0.95 & 0.54 & 7.00 & 10.49 & 29.19 & 3.37 & 54.11 & 4.70 & 18.94 & 5.78 & 1.14 & 2.07 \\
\hline Japan & 17.91 & 27,306 & 2,935 & -3.48 & 1.30 & 7.00 & 6.00 & 1.75 & 0.44 & 2.40 & 10.54 & 22.32 & 10.04 & 42.17 & 3.77 & 30.59 & 5.80 & 0.97 & -0.27 \\
\hline Korea & 6.77 & 10,317 & 1,392 & 0.14 & 0.97 & 8.00 & 6.00 & 0.98 & 0.99 & 0.59 & 9.97 & 24.83 & 3.54 & 28.29 & 5.32 & 34.05 & 4.77 & 0.94 & 2.96 \\
\hline Malaysia & 3.96 & 6,037 & 715 & 0.04 & 0.52 & 10.00 & 6.00 & 1.05 & 0.54 & 4.81 & 8.92 & 21.84 & 4.26 & 34.03 & 5.23 & 37.86 & 3.76 & 0.92 & 2.03 \\
\hline Mexico & 0.47 & 722 & 84 & 2.65 & -0.54 & 5.00 & 6.00 & 0.20 & 0.59 & 2.44 & 9.04 & 23.15 & 3.46 & 75.54 & 7.36 & 49.23 & 6.39 & 1.09 & 4.55 \\
\hline Netherlands & 0.59 & 895 & 98 & 0.79 & 1.76 & 6.00 & 5.00 & 1.74 & 0.88 & 2.00 & 10.79 & 24.90 & 4.05 & 68.17 & 7.14 & 18.87 & 6.61 & 1.33 & 1.67 \\
\hline New Zealand & 0.44 & 673 & 84 & 2.28 & 1.87 & 10.00 & 5.00 & 1.30 & 0.76 & 0.90 & 10.25 & 25.89 & 4.01 & 85.09 & 8.11 & 39.96 & 4.64 & 1.28 & 2.50 \\
\hline Norway & 0.64 & 977 & 128 & 0.06 & 1.92 & 6.00 & 4.00 & 0.84 & 0.95 & 1.28 & 11.38 & 34.98 & 2.15 & 81.90 & 4.85 & 31.37 & 5.38 & 1.18 & 2.17 \\
\hline Pakistan & 0.96 & 1,470 & 195 & 3.73 & -0.88 & 6.00 & 4.00 & 0.24 & 0.42 & 12.15 & 6.93 & 37.48 & 2.44 & 38.97 & 8.92 & 52.14 & 3.90 & 1.06 & 9.06 \\
\hline Peru & 0.38 & 580 & 76 & 0.65 & -0.61 & 7.00 & 6.00 & 0.21 & 0.75 & 3.03 & 8.23 & 22.81 & 6.11 & 53.98 & 9.62 & 47.80 & 4.63 & 1.01 & 2.00 \\
\hline Philippines & 0.62 & 943 & 124 & 2.05 & -0.54 & 4.00 & 3.00 & 0.29 & 0.48 & 5.80 & 7.55 & 24.43 & 2.83 & 47.44 & 5.88 & 39.37 & 3.95 & 0.98 & 4.65 \\
\hline Portugal & 0.29 & 443 & 48 & -0.73 & 1.04 & 3.00 & 5.00 & 1.53 & 0.85 & 3.61 & 9.95 & 29.24 & 2.16 & 61.67 & 4.29 & 34.89 & 5.93 & 1.09 & 2.74 \\
\hline Singapore & 2.64 & 4,021 & 501 & -0.83 & 1.64 & 10.00 & 3.00 & 0.98 & 0.94 & 1.50 & 10.51 & 20.20 & 6.09 & 33.97 & 5.73 & 27.23 & 4.19 & 1.04 & 1.66 \\
\hline South Africa & 1.13 & 1,728 & 220 & 5.71 & 0.08 & 10.00 & 6.00 & 1.41 & 0.78 & 3.92 & 8.69 & 16.71 & 6.01 & 55.93 & 12.41 & 24.71 & 5.31 & 1.27 & 5.70 \\
\hline Spain & 0.64 & 981 & 106 & -0.35 & 1.13 & 6.00 & 5.00 & 1.71 & 0.72 & 2.81 & 10.31 & 30.67 & 3.57 & 61.71 & 6.32 & 31.67 & 6.37 & 1.24 & 3.07 \\
\hline Sweden & 1.31 & 1,990 & 283 & 0.10 & 1.91 & 8.00 & 4.00 & 1.03 & 0.95 & 0.70 & 10.86 & 19.39 & 4.28 & 70.84 & 5.62 & 13.05 & 4.70 & 1.39 & 1.92 \\
\hline Switzerland & 0.96 & 1,464 & 157 & -0.74 & 1.81 & 8.00 & 5.00 & 1.60 & 0.89 & 0.86 & 11.05 & 18.22 & 6.98 & 67.48 & 7.15 & 25.57 & 6.10 & 1.28 & 0.73 \\
\hline Thailand & 2.16 & 3,292 & 415 & -0.71 & -0.13 & 5.00 & 5.00 & 1.00 & 0.47 & 5.70 & 8.23 & 28.61 & 5.53 & 34.85 & 7.59 & 40.51 & 4.15 & 1.06 & 3.27 \\
\hline Turkey & 1.22 & 1,854 & 222 & 3.47 & 0.08 & 4.00 & 5.00 & 0.26 & 0.48 & 3.49 & 9.11 & 20.37 & 2.58 & 30.74 & 7.35 & 35.91 & 4.70 & 1.15 & 9.60 \\
\hline UK & 4.20 & 6,401 & 831 & 1.02 & 1.68 & 10.00 & 6.00 & 1.72 & 0.56 & 2.50 & 10.61 & 18.71 & 4.24 & 27.25 & 6.11 & 18.58 & 5.05 & 1.34 & 2.32 \\
\hline USA & 18.17 & 27,701 & 3,863 & 1.08 & 1.57 & 9.00 & 6.00 & 1.93 & 0.32 & 2.97 & 10.78 & 26.85 & 2.05 & 83.92 & 4.76 & 20.40 & 5.43 & 1.60 & 2.83 \\
\hline Mean & & & & 3.72 & 1.12 & 7.75 & 5.36 & 1.32 & 0.53 & 3.06 & 9.94 & 32.73 & 18.24 & 51.38 & -5.79 & 32.36 & 4.93 & 1.96 & 2.78 \\
\hline Median & & & & -0.06 & 1.32 & 8.00 & 6.00 & 1.37 & 0.46 & 2.40 & 10.53 & 24.51 & 3.78 & 54.21 & 5.36 & 28.83 & 4.95 & 1.14 & 2.33 \\
\hline
\end{tabular}


Table 2. Correlations.

This table presents the correlation matrix. ADJ_COST is the industry-median adjusted cost of debt. LEV is the ratio between total debt and total assets. EBIT/INT is the ratio between earnings before interest and taxes and interest. MAT is the ratio between long-term debt and total debt. PROF is the ratio between EBIT and total assets. TANG is the ratio between tangible fixed assets and total assets. SIZE is the natural logarithm of sales. MTB is the market value of equity plus the book value of total assets minus the book value of equity, all divided by the book value of total assets. INF is the rate of inflation. R_LAW is one of the six dimensions of the WGI and is a measure of the efficiency of the legal system. LEG_IND measures the protection of borrowers and lenders' rights. DEP INF measures the depth of credit information. B CREDIT is the ratio of private credit by deposit money banks to GDP. B CONC is the fraction of assets held by the three largest commercial banks in each country. NPL measures the ratio of bank nonperforming loans to total gross loans (\%). GNI_PC is the natural logarithm of Gross National Income per capita. ***,**, and * represent significance at the $1 \%, 5 \%$, and $10 \%$ levels, respectively.

\begin{tabular}{|c|c|c|c|c|c|c|c|c|c|c|c|c|c|c|c|}
\hline & $\overline{\text { ADJ_COST }}$ & $\begin{array}{l}\text { LEV } \\
\end{array}$ & 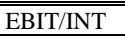 & MAT & $\begin{array}{l}\text { PROF } \\
\end{array}$ & $\begin{array}{l}\text { TANG } \\
\end{array}$ & $\begin{array}{l}\text { SIZE } \\
\end{array}$ & MTB & $\begin{array}{l}\mathrm{INF} \\
\end{array}$ & R_LAW & \begin{tabular}{|l|l|l|} 
LEG_IND \\
\end{tabular} & DEP_INF & B_CREDIT & B_CONC & NPL \\
\hline LEV & -0.002 & & & & & & & & & & & & & & \\
\hline EBIT/INT & 0.001 & -0.004 & & & & & & & & & & & & & \\
\hline MAT & -0.003 & $-0.006^{* *}$ & -0.001 & & & & & & & & & & & & \\
\hline PROF & 0.000 & $-0.061^{* * *}$ & $0.024^{* * * *}$ & 0.002 & & & & & & & & & & & \\
\hline TANG & $-0.013^{* * *}$ & -0.000 & $-0.009^{* * * *}$ & $0.041^{* * *}$ & 0.003 & & & & & & & & & & \\
\hline SIZE & $-0.007^{* * *}$ & $-0.108^{* * * *}$ & $0.025^{* * *}$ & $0.046^{* * *}$ & $0.014^{* * *}$ & $0.047^{* * * *}$ & & & & & & & & & \\
\hline MTB & 0.000 & $0.032^{* * * *}$ & $\begin{array}{l}-0.003 \\
-0.003\end{array}$ & $\begin{array}{l}-0.001 \\
-0.001\end{array}$ & $-0.142^{* * * *}$ & $\begin{array}{l}-0.005^{* *} \\
\end{array}$ & $-00140^{* * * *}$ & & & & & & & & \\
\hline INF & $0.011^{* * *}$ & 0.034 & $-0.008^{* * *}$ & -0.004 & 0.000 & $0.074^{* * * *}$ & $-0.123^{* * * *}$ & -0.001 & & & & & & & \\
\hline R_LAW & $-0.011^{* * * *}$ & $0.014^{* * *}$ & -0.004 & $0.026^{* * *}$ & $\begin{array}{l}-0.004^{*} \\
\end{array}$ & $\begin{array}{l}-0.161^{* * * *} \\
-\end{array}$ & $0.074^{* * * *}$ & 0.003 & $-0.543^{* * *}$ & & & & & & \\
\hline LEG_IND & $-0.011^{* * * *}$ & $0.014^{* * *}$ & $-0.006^{* *}$ & $0.013^{* * * *}$ & $\begin{array}{l}-0.004 \\
-0.004\end{array}$ & $-0.089^{* * * * *}$ & $-0.101^{* * * *}$ & 0.004 & $-0.109^{* * * *}$ & $0.460^{* * * *}$ & & & & & \\
\hline DEP INF & 0.001 & $0.020^{* * *}$ & 0.004 & $0.006^{* *}$ & -0.004 & $-0.028^{* * * *}$ & $0.086^{* * *}$ & 0.004 & $-0.268^{* * *}$ & $0.311^{* * * *}$ & $0.273^{* * *}$ & & & & \\
\hline B CREDIT & $-0.014^{* * *}$ & $0.028^{* * *}$ & 0.004 & $0.022^{* * *}$ & $-0.006^{* *}$ & $-0.134^{* * * *}$ & $0.142^{* * * *}$ & $0.005^{*}$ & $-0.544^{* * *}$ & $0.725^{* * * *}$ & $0.382^{* * * *}$ & $0.621^{* * * *}$ & & & \\
\hline B_CONC & -0.000 & $-0.032^{* * * *}$ & $\begin{array}{l}-0.004 \\
-0.004\end{array}$ & $\begin{array}{l}-0.015^{* * * *} \\
\text { - }\end{array}$ & $0.005^{*}$ & $-0.023^{* * * *}$ & $-0.018^{* * * *}$ & $-0.006^{* *}$ & $-0.034^{* * * *}$ & $0.190^{* * * *}$ & $0.018^{* * * *}$ & $\begin{array}{l}-0.376^{* * * *} \\
\text { (n) }\end{array}$ & $-0.267^{* * * *}$ & & \\
\hline $\begin{array}{l}\text { D_CUNC } \\
\text { NPL }\end{array}$ & $\begin{array}{r}-0.000 \\
0.000\end{array}$ & $\begin{array}{l}-0.032 \\
0.001\end{array}$ & $\begin{array}{l}-0.004 \\
-0.001\end{array}$ & $\begin{array}{l}-0.013 \text { * }-014^{* * *} \\
-0.04\end{array}$ & $\begin{array}{l}0.003 \\
-0.001\end{array}$ & $\begin{array}{l}-0.0234^{* * * *} \\
-0.08 *\end{array}$ & $\begin{array}{l}-0.0187^{* * * *} \\
-0.03 *\end{array}$ & $\begin{array}{l}-0.000 \\
-0.002\end{array}$ & $\begin{array}{l}-0.0545^{* * *} \\
0.165^{*}\end{array}$ & $\begin{array}{l}0.1901^{* * * *} \\
-0.43\end{array}$ & $\begin{array}{l}-0.29186^{* * * *} \\
-\end{array}$ & $\begin{array}{l}-0.5 / 0 \\
-0.220^{* * * *}\end{array}$ & $\begin{array}{l}-0.2018^{* * * *} \\
-0.23 *\end{array}$ & $-0.073^{* * * *}$ & \\
\hline GNI_PC & $-0.005^{* *}$ & $0.016^{* * * *}$ & $\begin{array}{l}-0.000 \\
-0.00\end{array}$ & $-0.019^{* * * *}$ & -0.004 & 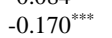 & $0.156^{* * * *}$ & 0.003 & $-0.594^{* * * *}$ & $0.889^{* * * *}$ & $0.227^{* * * *}$ & $0.429^{* * * *}$ & $0.772^{* * * *}$ & $0.151^{* * * *}$ & $0.348^{* * * *}$ \\
\hline
\end{tabular}


Table 3. Cost of debt, laws, institutions, and banking structure variables

Regressions are estimated using panel data. We use weighted regressions where the weights are the inverse of the \# firms in the country. The dependent variable (ADJ_COST) is the industry-median adjusted cost of debt. LEV is the ratio between total debt and total assets. EBIT/INT is the ratio between earnings before interest and taxes and interest. MAT is the ratio between long-term debt and total debt. PROF is the ratio between EBIT and total assets. TANG is the ratio between tangible fixed assets and total assets. SIZE is the natural logarithm of sales. MTB is the market value of equity plus the book value of total assets minus the book value of equity, all divided by the book value of total assets. INF is the rate of inflation. R LAW is one of the six dimensions of the WGI and is a measure of the efficiency of the legal system. LEG_IND measures the protection of borrowers and lenders' rights. DEP_INF measures the depth of credit information. B_CREDIT is the ratio of private credit by deposit money banks to GDP. B_CONC is the fraction of assets held by the three largest commercial banks in each country. NPL measures the ratio of bank non-performing loans to total gross loans (\%). We include industry and year fixed effects. The endogeneity test verifies the null hypothesis that the specified endogenous regressors can be treated as exogenous. We report instrumental variable estimations if the test is significant at the 10\% level. The weak identification test (Cragg-Donald Wald F statistic) tests the null hypothesis that instruments are weak. We compare the Cragg-Donald statistic to the critical values computed by Stock and Yogo (2005). First-stage regressions (not reported for the sake of conciseness) are available upon request. T-statistics are in parentheses. ***,**, and * represent significance at the $1 \%, 5 \%$, and $10 \%$ levels, respectively.

\begin{tabular}{|c|c|c|c|c|c|c|c|c|c|}
\hline & (1) & (2) & (3) & (4) & (5) & (6) & (7) & (8) & (9) \\
\hline LEV & $\begin{array}{c}-0.0434^{* * * *} \\
(-11.35)\end{array}$ & $\begin{array}{c}-0.0451^{* * *} \\
(-10.27)\end{array}$ & $\begin{array}{c}-0.0451^{* * * *} \\
(-10.27)\end{array}$ & $\begin{array}{c}-0.0438^{* * *} \\
(-10.94)\end{array}$ & $\begin{array}{c}-0.0452^{\text {**** }} \\
(-10.26)\end{array}$ & $\begin{array}{c}-0.0466^{* * *} \\
(-10.58)\end{array}$ & $\begin{array}{c}-0.0466^{* * *} \\
(-10.64)\end{array}$ & $\begin{array}{c}-0.0487^{* * * *} \\
(-9.49)\end{array}$ & $\begin{array}{c}-0.0487^{\text {**** }} \\
(-9.49)\end{array}$ \\
\hline EBIT/INT & $\begin{array}{c}0.0000^{* * *} \\
(2.23)\end{array}$ & $\begin{array}{c}0.0000 \\
(1.27)\end{array}$ & $\begin{array}{c}0.0000 \\
(1.26)\end{array}$ & $\begin{array}{c}0.0000^{* *} \\
(2.16)\end{array}$ & $\begin{array}{c}0.0000 \\
(1.23)\end{array}$ & $\begin{array}{c}0.0000^{* * *} \\
(2.33)\end{array}$ & $\begin{array}{c}0.0000^{* * *} \\
(2.22)\end{array}$ & $\begin{array}{c}0.0000 \\
(1.22)\end{array}$ & $\begin{array}{c}0.0000 \\
(1.22)\end{array}$ \\
\hline MAT & $\begin{array}{c}-0.0232^{* * *} \\
(-5.10)\end{array}$ & $\begin{array}{c}-0.0216^{* * *} \\
(-3.94)\end{array}$ & $\begin{array}{c}-0.0216^{* * *} \\
(-3.94)\end{array}$ & $\begin{array}{c}-0.0232^{* * *} \\
(-4.62)\end{array}$ & $\begin{array}{c}-0.0215^{* * *} \\
(-3.90)\end{array}$ & $\begin{array}{c}-0.0229^{* * * *} \\
(-4.36)\end{array}$ & $\begin{array}{c}-0.0245^{\text {**** }} \\
(-4.55)\end{array}$ & $\begin{array}{c}-0.0214^{* * *} \\
(-3.12)\end{array}$ & $\begin{array}{c}-0.0215^{* * * *} \\
(-3.13)\end{array}$ \\
\hline PROF & $\begin{array}{c}-0.0155^{* * * *} \\
(-4.70)\end{array}$ & $\begin{array}{c}-0.0149^{* * * *} \\
(-3.89)\end{array}$ & $\begin{array}{c}-0.0149^{* * * *} \\
(-3.89)\end{array}$ & $\begin{array}{c}-0.0151^{* * * *} \\
(-4.23)\end{array}$ & $\begin{array}{c}-0.0149^{* * * *} \\
(-3.89)\end{array}$ & $\begin{array}{c}-0.0195^{* * *} \\
(-5.01)\end{array}$ & $\begin{array}{c}-0.0194^{* * * *} \\
(-5.02)\end{array}$ & $\begin{array}{c}-0.0189^{* * * *} \\
(-4.19)\end{array}$ & $\begin{array}{c}-0.0189^{\text {**** }} \\
(-4.19)\end{array}$ \\
\hline TANG & $\begin{array}{c}-0.0082 \\
(-0.72)\end{array}$ & $\begin{array}{c}-0.0027 \\
(-0.18)\end{array}$ & $\begin{array}{c}-0.0029 \\
(-0.20)\end{array}$ & $\begin{array}{c}-0.0049 \\
(-0.38)\end{array}$ & $\begin{array}{c}-0.0028 \\
(-0.19)\end{array}$ & $\begin{array}{c}-0.0081 \\
(-0.58)\end{array}$ & $\begin{array}{c}-0.0083 \\
(-0.59)\end{array}$ & $\begin{array}{c}0.0001 \\
(0.01)\end{array}$ & $\begin{array}{c}-0.0001 \\
(-0.00)\end{array}$ \\
\hline SIZE & $\begin{array}{c}-0.0103^{* * * *} \\
(-4.90)\end{array}$ & $\begin{array}{c}-0.0095^{* * *} \\
(-3.77)\end{array}$ & $\begin{array}{c}-0.0094^{* * *} \\
(-3.71)\end{array}$ & $\begin{array}{c}-0.0097^{\text {**** }} \\
(-4.15)\end{array}$ & $\begin{array}{c}-0.0094^{* * * *} \\
(-3.71)\end{array}$ & $\begin{array}{c}-0.0121^{* * * *} \\
(-4.67)\end{array}$ & $\begin{array}{c}-0.0115^{* * * *} \\
(-4.42)\end{array}$ & $\begin{array}{c}-0.0103^{\text {**** }} \\
(-3.11)\end{array}$ & $\begin{array}{c}-0.0104^{* * * *} \\
(-3.13)\end{array}$ \\
\hline MTB & $\begin{array}{c}0.0020^{* * * *} \\
(3.89)\end{array}$ & $\begin{array}{c}0.0021^{* * *} \\
(3.61)\end{array}$ & $\begin{array}{c}0.0021^{* * * *} \\
(3.62)\end{array}$ & $\begin{array}{c}0.0021^{* * *} \\
(3.71)\end{array}$ & $\begin{array}{c}0.0021^{* * * *} \\
(3.61)\end{array}$ & $\begin{array}{c}0.0020^{* * * *} \\
(3.54)\end{array}$ & $\begin{array}{c}0.0020^{* * * *} \\
(3.56)\end{array}$ & $\begin{array}{c}0.0021^{* * * *} \\
(3.27)\end{array}$ & $\begin{array}{c}0.0021^{* * * *} \\
(3.28)\end{array}$ \\
\hline INF & $\begin{array}{c}0.2843^{* * *} \\
(7.50)\end{array}$ & $\begin{array}{c}0.1290^{* * *} \\
(2.44)\end{array}$ & $\begin{array}{c}0.1577^{* * * *} \\
(2.86)\end{array}$ & $\begin{array}{c}0.2646^{* * * *} \\
(6.25)\end{array}$ & $\begin{array}{c}0.2169^{* * * *} \\
(4.53)\end{array}$ & $\begin{array}{c}0.2973^{* * *} \\
(6.77)\end{array}$ & $\begin{array}{c}0.2810^{* * * *} \\
(6.70)\end{array}$ & $\begin{array}{c}0.3944^{* * * *} \\
(3.48)\end{array}$ & $\begin{array}{c}0.3764^{* * * *} \\
(3.46)\end{array}$ \\
\hline R_LAW & & $\begin{array}{c}-0.0503^{* * * *} \\
(-4.38)\end{array}$ & $\begin{array}{c}-0.1054^{* * *} \\
(-4.41)\end{array}$ & & & & & $\begin{array}{c}-0.3134^{* * *} \\
(-4.67)\end{array}$ & $\begin{array}{c}-0.3119^{* * * *} \\
(-4.51)\end{array}$ \\
\hline LEG_IND & & $\begin{array}{c}-0.0020 \\
(-1.07)\end{array}$ & $\begin{array}{c}-0.0079^{* * *} \\
(-2.76)\end{array}$ & & $\begin{array}{c}-0.0030 \\
(-1.12)\end{array}$ & & & $\begin{array}{c}-0.0521^{\text {**** }} \\
(-3.58)\end{array}$ & $\begin{array}{c}-0.0570^{* * * *} \\
(-3.78)\end{array}$ \\
\hline R_LAW*LEG_IND & & & $\begin{array}{c}0.0068^{* * * *} \\
(2.74)\end{array}$ & & & & & $\begin{array}{c}0.0384^{* * * *} \\
(4.53)\end{array}$ & $\begin{array}{c}0.0376^{* * * *} \\
(4.44)\end{array}$ \\
\hline DEP_INF & & & & $\begin{array}{c}-0.0011 \\
(-1.33)\end{array}$ & $\begin{array}{c}-0.0032 \\
(-0.69)\end{array}$ & & & $\begin{array}{c}0.0194^{* *} \\
(2.47)\end{array}$ & $\begin{array}{c}0.0064 \\
(0.92)\end{array}$ \\
\hline DEP_INF*LEG_IND & & & & & $\begin{array}{c}0.0006 \\
(0.87)\end{array}$ & & & $\begin{array}{c}0.0004 \\
(0.26)\end{array}$ & $\begin{array}{c}0.0016 \\
(1.16)\end{array}$ \\
\hline B_CREDIT & & & & & & $\begin{array}{c}0.0149 \\
(1.01)\end{array}$ & & $\begin{array}{c}-0.1167^{* * *} \\
(-3.55)\end{array}$ & $\begin{array}{c}-0.1113^{\text {*** }} \\
(-3.81)\end{array}$ \\
\hline B_CREDIT*NPL & & & & & & & & & $\begin{array}{c}0.0038^{*} \\
(1.68)\end{array}$ \\
\hline B_CONC & & & & & & & $\begin{array}{c}0.0880^{* * * *} \\
(5.07)\end{array}$ & $\begin{array}{c}0.0458^{* *} \\
(1.96)\end{array}$ & $\begin{array}{c}0.0365 \\
(1.45)\end{array}$ \\
\hline B_CONC*NPL & & & & & & & & & $\begin{array}{c}0.0121^{\text {** }} \\
(2.08)\end{array}$ \\
\hline NPL & & & & & & & & & $\begin{array}{c}-0.0106^{* *} \\
(-2.01)\end{array}$ \\
\hline Industry-year effects & Yes & Yes & Yes & Yes & Yes & Yes & Yes & Yes & Yes \\
\hline F test & $4.70^{* * * *}$ & $4.56^{* * * *}$ & $4.56^{* * * *}$ & $4.64^{* * * *}$ & $4.18^{* * * *}$ & $3.99^{* * * *}$ & $4.36^{* * *}$ & $3.65^{* * *}$ & $3.91^{* * *}$ \\
\hline \#observations & 152,432 & 131,648 & 131,648 & 139,319 & 128,810 & 125,068 & 123,886 & 97,981 & 97,981 \\
\hline \#firms & 19,785 & 19,506 & 19,506 & 19,597 & 19,467 & 17,742 & 18,027 & 17,249 & 17,249 \\
\hline Endogeneity test & - & - & - & - & - & $12.74^{* * * *}$ & $21.36^{* * * *}$ & $26.93^{* * * *}$ & $18.90^{* * * *}$ \\
\hline Cragg-Donald stat. & - & - & - & - & - & 6991.53 & 10000 & 1428.99 & 2028.05 \\
\hline $\begin{array}{l}\text { Stock \& Yogo critical } \\
\text { value }(10 \%)\end{array}$ & - & - & - & - & - & 10.27 & 10.27 & 7.56 & 7.56 \\
\hline
\end{tabular}


Table 4. Economic development: Cost of debt, laws, institutions, and banking structure variables

Regressions are estimated using panel data. We use weighted regressions where the weights are the inverse of the \# firms in the country. The dependent variable (ADJ_COST) is the industry-median adjusted cost of debt. LEV is the ratio between total debt and total assets. EBIT/INT is the ratio between earnings before interest and taxes and interest. MAT is the ratio between long-term debt and total debt. PROF is the ratio between EBIT and total assets. TANG is the ratio between tangible fixed assets and total assets. SIZE is the natural logarithm of sales. MTB is the market value of equity plus the book value of total assets minus the book value of equity, all divided by the book value of total assets. INF is the rate of inflation. R LAW is one of the six dimensions of the WGI and is a measure of the efficiency of the legal system. LEG_IND measures the protection of borrowers and lenders' rights. DEP_INF measures the depth of credit information. B_CREDIT is the ratio of private credit by deposit money banks to GDP. B_CONC is the fraction of assets held by the three largest commercial banks in each country. GNI_PC is the natural logarithm of Gross National Income per capita. We include industry and year fixed effects. The endogeneity test verifies the null hypothesis that the specified endogenous regressors can be treated as exogenous. We report instrumental variable estimations if the test is significant at the $10 \%$ level. The weak identification test (Cragg-Donald Wald $\mathrm{F}$ statistic) tests the null hypothesis that instruments are weak. We compare the Cragg-Donald statistic to the critical values computed by Stock and Yogo (2005). Firststage regressions (not reported for the sake of conciseness) are available upon request. T-statistics are in parentheses. ***,**, and * represent significance at the $1 \%, 5 \%$, and $10 \%$ levels, respectively.

\begin{tabular}{|c|c|c|c|c|c|c|c|}
\hline & (1) & (2) & (3) & (4) & (5) & (6) & (7) \\
\hline LEV & $\begin{array}{c}-0.0436^{* * *} \\
(-11.35)\end{array}$ & $\begin{array}{c}-0.0437^{* * * *} \\
(-11.38)\end{array}$ & $\begin{array}{c}-0.0454^{* * * *} \\
(-10.27)\end{array}$ & $\begin{array}{c}-0.0440^{* * * *} \\
(-10.93)\end{array}$ & $\begin{array}{c}-0.0468^{* * * *} \\
(-10.62)\end{array}$ & $\begin{array}{c}-0.0465^{* * * *} \\
(-10.63)\end{array}$ & $\begin{array}{c}-0.0490^{* * * *} \\
(-9.55)\end{array}$ \\
\hline EBIT/INT & $\begin{array}{c}0.0000^{* * *} \\
(2.12)\end{array}$ & $\begin{array}{c}0.0000^{* * *} \\
(2.24)\end{array}$ & $\begin{array}{c}0.0000 \\
(1.26)\end{array}$ & $\begin{array}{c}0.0000^{* * *} \\
(2.12)\end{array}$ & $\begin{array}{c}0.0000^{* *} \\
(2.32)\end{array}$ & $\begin{array}{c}0.0000^{* *} \\
(2.13)\end{array}$ & $\begin{array}{c}0.0000 \\
(1.41)\end{array}$ \\
\hline MAT & $\begin{array}{c}-0.0240^{* * * *} \\
(-5.11)\end{array}$ & $\begin{array}{c}-0.0241^{* * * *} \\
(-5.13)\end{array}$ & $\begin{array}{c}-0.0224^{* * * *} \\
(-3.95)\end{array}$ & $\begin{array}{c}-0.0240^{* * * *} \\
(-4.62)\end{array}$ & $\begin{array}{c}-0.0230^{* * *} \\
(-4.37)\end{array}$ & $\begin{array}{c}-0.0241^{* * * *} \\
(-4.46)\end{array}$ & $\begin{array}{c}-0.0214^{* * * *} \\
(-3.13)\end{array}$ \\
\hline PROF & $\begin{array}{c}-0.0155^{* * * *} \\
(-4.69)\end{array}$ & $\begin{array}{c}-0.0155^{* * * *} \\
(-4.69)\end{array}$ & $\begin{array}{c}-0.0149^{* * * *} \\
(-3.88)\end{array}$ & $\begin{array}{c}-0.0151^{* * * *} \\
(-4.22)\end{array}$ & $\begin{array}{c}-0.0196^{* * *} \\
(-5.04)\end{array}$ & $\begin{array}{c}-0.0194^{* * *} \\
(-5.02)\end{array}$ & $\begin{array}{c}-0.0189^{* * *} \\
(-4.19)\end{array}$ \\
\hline TANG & $\begin{array}{c}-0.0102 \\
(-0.84)\end{array}$ & $\begin{array}{c}-0.0094 \\
(-0.77)\end{array}$ & $\begin{array}{c}-0.0032 \\
(-0.21)\end{array}$ & $\begin{array}{c}-0.0058 \\
(-0.42)\end{array}$ & $\begin{array}{c}-0.0082 \\
(-0.59)\end{array}$ & $\begin{array}{c}-0.0092 \\
(-0.65)\end{array}$ & $\begin{array}{c}-0.0002 \\
(-0.01)\end{array}$ \\
\hline SIZE & $\begin{array}{c}-0.0103^{* * * *} \\
(-4.57)\end{array}$ & $\begin{array}{c}-0.0105^{* * *} \\
(-4.66)\end{array}$ & $\begin{array}{c}-0.0098^{* * * *} \\
(-3.62)\end{array}$ & $\begin{array}{c}-0.0100^{* * * *} \\
(-3.98)\end{array}$ & $\begin{array}{c}-0.0116^{* * * *} \\
(-4.43)\end{array}$ & $\begin{array}{c}-0.0113^{* * * *} \\
(-4.31)\end{array}$ & $\begin{array}{c}-0.0110^{* * *} \\
(-3.31)\end{array}$ \\
\hline MTB & $\begin{array}{c}0.0021^{* * * *} \\
(3.90)\end{array}$ & $\begin{array}{c}0.0021^{* * *} \\
(3.90)\end{array}$ & $\begin{array}{c}0.0021^{* * *} \\
(3.62)\end{array}$ & $\begin{array}{c}0.0021^{* * * *} \\
(3.72)\end{array}$ & $\begin{array}{c}0.0020^{* * * *} \\
(3.57)\end{array}$ & $\begin{array}{c}0.0020^{* * *} \\
(3.57)\end{array}$ & $\begin{array}{c}0.0021^{* * * *} \\
(3.31)\end{array}$ \\
\hline INF & $\begin{array}{c}0.3275^{* * * *} \\
(7.84)\end{array}$ & $\begin{array}{c}0.2018^{* * *} \\
(4.64)\end{array}$ & $\begin{array}{c}0.2317^{* * *} \\
(4.41)\end{array}$ & $\begin{array}{c}0.2866^{* * *} \\
(6.14)\end{array}$ & $\begin{array}{c}0.3563^{* * * *} \\
(8.11)\end{array}$ & $\begin{array}{c}0.3353^{* * *} \\
(6.41)\end{array}$ & $\begin{array}{c}0.0649 \\
(0.73)\end{array}$ \\
\hline R_LAW & & $\begin{array}{c}-0.4306^{* * *} \\
(-10.80)\end{array}$ & & & & & $\begin{array}{c}-0.6653^{* * *} \\
(-5.49)\end{array}$ \\
\hline R_LAW*GNI_PC & & $\begin{array}{c}0.0378^{* * *} \\
(9.58)\end{array}$ & & & & & $\begin{array}{c}0.0596^{* * *} \\
(5.19)\end{array}$ \\
\hline LEG_IND & & & $\begin{array}{c}-0.0179^{* * * *} \\
(-2.69)\end{array}$ & & & & $\begin{array}{c}-0.0509^{* *} \\
(-2.36)\end{array}$ \\
\hline LEG_IND*GNI_PC & & & $\begin{array}{c}0.0020^{* * *} \\
(2.61)\end{array}$ & & & & $\begin{array}{c}0.0046^{* *} \\
(2.11)\end{array}$ \\
\hline DEP_INF & & & & $\begin{array}{c}-0.0038 \\
(-0.94)\end{array}$ & & & $\begin{array}{c}0.0614^{* * *} \\
(3.21)\end{array}$ \\
\hline DEP_INF*GNI_PC & & & & $\begin{array}{l}0.0006 \\
(1.15)\end{array}$ & & & $\begin{array}{c}-0.0060^{* * * *} \\
(-2.78)\end{array}$ \\
\hline B_CREDIT & & & & & $\begin{array}{c}0.0515^{* * *} \\
(3.93)\end{array}$ & & $\begin{array}{c}-0.3670^{* * * *} \\
(-3.08)\end{array}$ \\
\hline B_CREDIT*GNI_PC & & & & & $\begin{array}{c}-0.0008 \\
(-0.26)\end{array}$ & & $\begin{array}{c}0.0323^{* * *} \\
(2.82)\end{array}$ \\
\hline B_CONC & & & & & & $\begin{array}{c}0.0365^{* *} \\
(2.27)\end{array}$ & $\begin{array}{c}0.2133 \\
(0.86)\end{array}$ \\
\hline B_CONC*GNI_PC & & & & & & $\begin{array}{c}0.0090 \\
(0.61)\end{array}$ & $\begin{array}{c}-0.0244 \\
(-0.99)\end{array}$ \\
\hline GNI_PC & $\begin{array}{c}-0.0222^{* * * *} \\
(-3.99)\end{array}$ & $\begin{array}{c}-0.0549^{* * * *} \\
(-7.67)\end{array}$ & $\begin{array}{c}-0.0096 \\
(-1.11) \\
\end{array}$ & $\begin{array}{c}-0.0181^{* * * *} \\
(-2.58)\end{array}$ & $\begin{array}{c}-0.0379^{* * *} \\
(-5.01)\end{array}$ & $\begin{array}{c}-0.0247^{* *} \\
(-2.44)\end{array}$ & $\begin{array}{c}-0.0949^{* * * *} \\
(-3.15)\end{array}$ \\
\hline Industry-year effects & Yes & Yes & Yes & Yes & Yes & Yes & Yes \\
\hline F test & $5.32^{* * * *}$ & $5.49^{* * * *}$ & $4.54^{* * *}$ & $5.26^{* * * k}$ & $4.39^{* * * *}$ & $4.45^{* * * k}$ & $4.99^{* * *}$ \\
\hline \#observations & 145,685 & 145,685 & 125,904 & 133,057 & 125,068 & 123,886 & 97,981 \\
\hline \#firms & 18,976 & 18,976 & 18,705 & 18,791 & 17,742 & 18,027 & 17,249 \\
\hline Endogeneity test & - & - & - & - & $17.70^{* * * *}$ & $4.42^{* *}$ & 1.94 \\
\hline Cragg-Donald stat. & - & - & - & - & 11000 & 12000 & - \\
\hline Stock \& Yogo critical value (10\%) & - & - & - & - & 10.27 & 10.27 & - \\
\hline
\end{tabular}


Table 5. Robustness analysis. Alternative measure of cost of debt.

Regressions are estimated using panel data. We use weighted regressions where the weights are the inverse of the \# firms in the country. The dependent variable is the cost of debt adjusted by industry median or government 5-year bond yield. LEV is the ratio between total debt and total assets. EBIT/INT is the ratio between earnings before interest and taxes and interest. MAT is the ratio between long-term debt and total debt. PROF is the ratio between EBIT and total assets. TANG is the ratio between tangible fixed assets and total assets. SIZE is the natural logarithm of sales. MTB is the market value of equity plus the book value of total assets minus the book value of equity, all divided by the book value of total assets. INF is the rate of inflation. R_LAW is one of the six dimensions of the WGI and is a measure of the efficiency of the legal system. LEG_IND measures the protection of borrowers and lenders' rights. DEP_INF measures the depth of credit information. B_CREDIT is the ratio of private credit by deposit money banks to GDP. B_CONC is the fraction of assets held by the three largest commercial banks in each country. NPL measures the ratio of bank non-performing loans to total gross loans (\%). GNI_PC is the natural logarithm of Gross National Income per capita. We include industry and year fixed effects. The endogeneity test verifies the null hypothesis that the specified endogenous regressors can be treated as exogenous. We report instrumental variable estimations if the test is significant at the $10 \%$ level. The weak identification test (Cragg-Donald Wald F statistic) tests the null hypothesis that instruments are weak. We compare the Cragg-Donald statistic to the critical values computed by Stock and Yogo (2005). First-stage regressions (not reported for the sake of conciseness) are available upon request. T-statistics are in parentheses. $* * *, * *$, and * represent significance at the $1 \%, 5 \%$, and $10 \%$ levels, respectively.

\begin{tabular}{|c|c|c|c|c|}
\hline \multirow[t]{2}{*}{ DEPENDENT VARIABLE } & \multicolumn{2}{|c|}{$\begin{array}{l}\text { INDUSTRY MEDIAN-ADJUSTED } \\
\text { COST OF DEBT }\end{array}$} & \multicolumn{2}{|c|}{$\begin{array}{l}\text { GOVT } 5 Y \text { BOND YIELD-ADJUSTED } \\
\text { COST OF DEBT }\end{array}$} \\
\hline & $(1)$ & $(2)$ & (3) & (4) \\
\hline LEV & $\begin{array}{c}-0.0487^{* * *} \\
(-9.49)\end{array}$ & $\begin{array}{c}-0.0490^{* * * *} \\
(-9.55)\end{array}$ & $\begin{array}{l}-0.0488^{* * * *} \\
(-9.49)\end{array}$ & $\begin{array}{c}-0.0488^{* * *} \\
(-9.49)\end{array}$ \\
\hline EBIT/INT & $\begin{array}{c}0.0000 \\
(1.22)\end{array}$ & $\begin{array}{c}0.0000 \\
(1.41)\end{array}$ & $\begin{array}{c}0.0000 \\
(1.29)\end{array}$ & $\begin{array}{l}0.0000 \\
(1.47)\end{array}$ \\
\hline MAT & $\begin{array}{c}-0.0215^{* * *} \\
(-3.13)\end{array}$ & $\begin{array}{c}-0.0214^{* * *} \\
(-3.13)\end{array}$ & $\begin{array}{c}-0.0214^{* * * *} \\
(-3.11)\end{array}$ & $\begin{array}{c}-0.0214^{* * *} \\
(-3.12)\end{array}$ \\
\hline PROF & $\begin{array}{c}-0.0189^{* * *} \\
(-4.19)\end{array}$ & $\begin{array}{l}-0.0189^{* * * *} \\
(-4.19)\end{array}$ & $\begin{array}{c}-0.0190^{* * * *} \\
(-4.19)\end{array}$ & $\begin{array}{l}-0.0190^{* * * *} \\
(-4.20)\end{array}$ \\
\hline TANG & $\begin{array}{c}-0.0001 \\
(-0.00)\end{array}$ & $\begin{array}{c}-0.0002 \\
(-0.01)\end{array}$ & $\begin{array}{c}0.0001 \\
(0.01)\end{array}$ & $\begin{array}{c}-0.0004 \\
(-0.02)\end{array}$ \\
\hline SIZE & $\begin{array}{c}-0.0104^{* * * *} \\
(-3.13)\end{array}$ & $\begin{array}{c}-0.0110^{* * * *} \\
(-3.31)\end{array}$ & $\begin{array}{c}-0.0105^{* * *} \\
(-3.17)\end{array}$ & $\begin{array}{c}-0.0108^{* * *} \\
(-3.27)\end{array}$ \\
\hline MTB & $\begin{array}{l}0.0021^{* * *} \\
(3.28)\end{array}$ & $\begin{array}{c}0.0021^{* * *} \\
(3.31)\end{array}$ & $\begin{array}{l}0.0021^{* * *} \\
(3.27)\end{array}$ & $\begin{array}{l}0.0021^{* * * *} \\
(3.25)\end{array}$ \\
\hline INF & $\begin{array}{l}0.3764^{* * * *} \\
\quad(3.46)\end{array}$ & $\begin{array}{r}0.0649 \\
(0.73)\end{array}$ & $\begin{array}{c}0.2399^{* *} \\
(2.20)\end{array}$ & $\begin{array}{c}-0.1093 \\
(-1.22)\end{array}$ \\
\hline R_LAW & $\begin{array}{c}-0.3119^{\text {*** }} \\
(-4.51)\end{array}$ & $\begin{array}{c}-0.6653^{* * *} \\
(-5.49)\end{array}$ & $\begin{array}{c}-0.2688^{\text {**** }} \\
(-3.87)\end{array}$ & $\begin{array}{c}-0.7792^{* * *} \\
(-6.41)\end{array}$ \\
\hline R_LAW*GNI_PC & & $\begin{array}{c}0.0596^{\text {*** }} \\
(5.19)\end{array}$ & & $\begin{array}{l}0.0731^{\text {**** }} \\
\quad(6.34)\end{array}$ \\
\hline LEG_IND & $\begin{array}{c}-0.0570^{* * *} \\
(-3.78)\end{array}$ & $\begin{array}{c}-0.0509^{* *} \\
(-2.36)\end{array}$ & $\begin{array}{c}-0.0528^{* * *} \\
(-3.49)\end{array}$ & $\begin{array}{c}-0.0509^{* *} \\
(-2.36)\end{array}$ \\
\hline LEG_IND*GNI_PC & & $\begin{array}{c}0.0046^{* *} \\
(2.11)\end{array}$ & & $\begin{array}{c}0.0046^{* *} \\
(2.10)\end{array}$ \\
\hline R_LAW*LEG_IND & $\begin{array}{c}0.0376^{* * * *} \\
(4.44)\end{array}$ & & $\begin{array}{c}0.0334^{* * * *} \\
(3.77)\end{array}$ & \\
\hline DEP_INF & $\begin{array}{c}0.0064 \\
(0.92)\end{array}$ & $\begin{array}{c}0.0614^{* * *} \\
(3.21)\end{array}$ & $\begin{array}{c}-0.0095 \\
(-1.36)\end{array}$ & $\begin{array}{c}0.0901^{* * *} \\
(4.70)\end{array}$ \\
\hline DEP_INF*GNI_PC & & $\begin{array}{c}-0.0060^{* * * *} \\
(-2.78)\end{array}$ & & $\begin{array}{c}-0.0102^{* * *} \\
(-4.74)\end{array}$ \\
\hline DEP_INF*LEG_IND & $\begin{array}{c}0.0016 \\
(1.16)\end{array}$ & & $\begin{array}{c}0.0026^{*} \\
(1.93)\end{array}$ & \\
\hline B_CREDIT & $\begin{array}{c}-0.1113^{* * *} \\
(-3.81)\end{array}$ & $\begin{array}{c}-0.3670^{* * *} \\
(-3.08)\end{array}$ & $\begin{array}{c}-0.0956^{\text {**** }} \\
(-3.27)\end{array}$ & $\begin{array}{c}-0.4283^{* * *} \\
(-3.58)\end{array}$ \\
\hline B_CREDIT*NPL & $\begin{array}{c}0.0038^{*} \\
(1.68)\end{array}$ & & $\begin{array}{c}0.0088^{* * * *} \\
(3.91)\end{array}$ & \\
\hline B_CREDIT*GNI_PC & & $\begin{array}{c}0.0323^{* * * *} \\
(2.82)\end{array}$ & & $\begin{array}{c}0.0381^{* * * *} \\
(3.32)\end{array}$ \\
\hline B_CONC & $\begin{array}{c}0.0365 \\
(1.45)\end{array}$ & $\begin{array}{c}0.2133 \\
(0.86)\end{array}$ & $\begin{array}{c}0.0083 \\
(0.33)\end{array}$ & $\begin{array}{c}-0.0796 \\
(-0.32)\end{array}$ \\
\hline B_CONC*NPL & $\begin{array}{c}0.0121^{* *} \\
(2.08)\end{array}$ & & $\begin{array}{c}0.0118^{* *} \\
(2.03)\end{array}$ & \\
\hline B_CONC*GNI_PC & & $\begin{array}{c}-0.0244 \\
(-0.99)\end{array}$ & & $\begin{array}{c}0.0028 \\
(0.11)\end{array}$ \\
\hline NPL & $\begin{array}{c}-0.0106^{* *} \\
(-2.01)\end{array}$ & & $\begin{array}{c}-0.0161^{* * *} \\
(-3.06)\end{array}$ & \\
\hline GNI_PC & & $\begin{array}{c}-0.0949^{* * * *} \\
(-3.15)\end{array}$ & & $\begin{array}{c}-0.1098^{* * *} \\
(-3.64)\end{array}$ \\
\hline Industry-year effects & Yes & Yes & Yes & Yes \\
\hline F test & $3.91^{* * *}$ & $4.99^{* * *}$ & $5.66^{* * *}$ & $4.16^{* * *}$ \\
\hline \#observations & 97,981 & 97,981 & 97,981 & 97,981 \\
\hline \#firms & 17,249 & 17,249 & 17,249 & 17,249 \\
\hline Endogeneity test & $18.90^{* * * *}$ & 1.94 & $7.47^{* * * *}$ & 2.57 \\
\hline Cragg-Donald stat. & 2028.05 & - & 2074.59 & - \\
\hline Stock \& Yogo critical value (10\%) & 7.56 & - & 7.56 & - \\
\hline
\end{tabular}


Table 6. Robustness analysis excluding the USA and Japan

Regressions are estimated using panel data. We use weighted regressions where the weights are the inverse of the \# firms in the country. The dependent variable is the cost of debt adjusted by industry median. LEV is the ratio between total debt and total assets. EBIT/INT is the ratio between earnings before interest and taxes and interest. MAT is the ratio between long-term debt and total debt. PROF is the ratio between EBIT and total assets. TANG is the ratio between tangible fixed assets and total assets. SIZE is the natural logarithm of sales. MTB is the market value of equity plus the book value of total assets minus the book value of equity, all divided by the book value of total assets. INF is the rate of inflation. R_LAW is one of the six dimensions of the WGI and is a measure of the efficiency of the legal system. LEG_IND measures the protection of borrowers and lenders' rights. DEP_INF measures the depth of credit information. B_CREDIT is the ratio of private credit by deposit money banks to GDP. B_CONC is the fraction of assets held by the three largest commercial banks in each country. NPL measures the ratio of bank non-performing loans to total gross loans $(\%)$. We include industry and year fixed effects. The endogeneity test verifies the null hypothesis that the specified endogenous regressors can be treated as exogenous. We report instrumental variable estimations if the test is significant at the $10 \%$ level. The weak identification test (Cragg-Donald Wald F statistic) tests the null hypothesis that instruments are weak. We compare the Cragg-Donald statistic to the critical values computed by Stock and Yogo (2005). First-stage regressions (not reported for the sake of conciseness) are available upon request. T-statistics are in parentheses. ***,**, and * represent significance at the $1 \%, 5 \%$, and $10 \%$ levels, respectively.

COMPLETE SAMPLE SAMPLE WITHOUT JAPAN SAMPLE WITHOUT USA

\begin{tabular}{|c|c|c|c|c|c|c|}
\hline & (1) & (2) & (3) & (4) & (5) & (6) \\
\hline LEV & $\begin{array}{c}-0.0487^{* * *} \\
(-9.49)\end{array}$ & $\begin{array}{c}-0.0487^{* * *} \\
(-9.49)\end{array}$ & $\begin{array}{c}-0.0494^{* * *} \\
(-9.48)\end{array}$ & $\begin{array}{c}-0.0494^{* * *} \\
(-9.48)\end{array}$ & $\begin{array}{c}-0.0614^{* * * *} \\
(-12.50)\end{array}$ & $\begin{array}{c}-0.0613^{* * *} \\
(-12.46)\end{array}$ \\
\hline EBIT/INT & $\begin{array}{c}0.0000 \\
(1.22)\end{array}$ & $\begin{array}{c}0.0000 \\
(1.22)\end{array}$ & $\begin{array}{c}0.0000^{*} \\
(1.77)\end{array}$ & $\begin{array}{c}0.0001^{*} \\
(1.77)\end{array}$ & $\begin{array}{c}-0.0000^{* * * *} \\
(-3.30)\end{array}$ & $\begin{array}{c}-0.0000^{* * * *} \\
(-3.34)\end{array}$ \\
\hline MAT & $\begin{array}{c}-0.0214^{* * *} \\
(-3.12)\end{array}$ & $\begin{array}{c}-0.0215^{* * *} \\
(-3.13)\end{array}$ & $\begin{array}{c}-0.0277^{* * *} \\
(-3.09)\end{array}$ & $\begin{array}{c}-0.0277^{* * *} \\
(-3.10)\end{array}$ & $\begin{array}{c}-0.0119^{* * * *} \\
(-5.32)\end{array}$ & $\begin{array}{c}-0.0119^{* * *} \\
(-5.34)\end{array}$ \\
\hline PROF & $\begin{array}{c}-0.0189^{* * * *} \\
(-4.19)\end{array}$ & $\begin{array}{c}-0.0189^{* * * *} \\
(-4.19)\end{array}$ & $\begin{array}{c}-0.0194^{* * *} \\
(-4.23)\end{array}$ & $\begin{array}{c}-0.0194^{* * * *} \\
(-4.23)\end{array}$ & $\begin{array}{c}-0.0032 \\
(-0.53)\end{array}$ & $\begin{array}{c}-0.0031 \\
(-0.51)\end{array}$ \\
\hline TANG & $\begin{array}{c}0.0001 \\
(0.01)\end{array}$ & $\begin{array}{c}-0.0001 \\
(-0.00)\end{array}$ & $\begin{array}{c}-0.0012 \\
(-0.06)\end{array}$ & $\begin{array}{c}-0.0015 \\
(-0.07)\end{array}$ & $\begin{array}{c}0.0107^{* *} \\
(2.19)\end{array}$ & $\begin{array}{c}0.0110^{* *} \\
(2.27)\end{array}$ \\
\hline SIZE & $\begin{array}{c}-0.0103^{* * *} \\
(-3.11)\end{array}$ & $\begin{array}{c}-0.0104^{* * * *} \\
(-3.13)\end{array}$ & $\begin{array}{c}-0.0118^{* * * *} \\
(-3.27)\end{array}$ & $\begin{array}{c}-0.0118^{* * * *} \\
(-3.28)\end{array}$ & $\begin{array}{c}-0.0017 \\
(-1.60)\end{array}$ & $\begin{array}{c}-0.0016 \\
(-1.56)\end{array}$ \\
\hline MTB & $\begin{array}{c}0.0021^{* * * *} \\
(3.27)\end{array}$ & $\begin{array}{c}0.0021^{* * *} \\
(3.28)\end{array}$ & $\begin{array}{c}0.0021^{\text {**** }} \\
(3.21)\end{array}$ & $\begin{array}{c}0.0021^{* * *} \\
(3.21)\end{array}$ & $\begin{array}{c}0.0028^{* * * *} \\
(2.76)\end{array}$ & $\begin{array}{c}0.0029^{* * * *} \\
(2.81)\end{array}$ \\
\hline INF & $\begin{array}{c}0.3944^{* * * *} \\
(3.48)\end{array}$ & $\begin{array}{c}0.3764^{* * *} \\
(3.46)\end{array}$ & $\begin{array}{c}0.3301^{* * *} \\
(3.07)\end{array}$ & $\begin{array}{c}0.3381^{\text {**** }} \\
(2.75)\end{array}$ & $\begin{array}{c}0.3337^{* * *} \\
(4.75)\end{array}$ & $\begin{array}{c}0.3426^{* * * *} \\
(4.54)\end{array}$ \\
\hline R_LAW & $\begin{array}{c}-0.3134^{* * *} \\
(-4.67)\end{array}$ & $\begin{array}{c}-0.3119^{* * * *} \\
(-4.51)\end{array}$ & $\begin{array}{c}-0.2642^{* * *} \\
(-3.78)\end{array}$ & $\begin{array}{c}-0.2842^{* * * *} \\
(-3.55)\end{array}$ & $\begin{array}{c}-0.3621^{* * * *} \\
(-5.38)\end{array}$ & $\begin{array}{c}-0.3667^{* * *} \\
(-5.47)\end{array}$ \\
\hline LEG_IND & $\begin{array}{c}-0.0521^{* * * *} \\
(-3.58)\end{array}$ & $\begin{array}{c}-0.0570^{* * * *} \\
(-3.78)\end{array}$ & $\begin{array}{c}-0.0490^{* * *} \\
(-3.26)\end{array}$ & $\begin{array}{c}-0.0626^{\text {**** }} \\
(-3.31)\end{array}$ & $\begin{array}{c}-0.0698^{* * *} \\
(-4.86)\end{array}$ & $\begin{array}{c}-0.0754^{\text {*** }} \\
(-5.27)\end{array}$ \\
\hline R_LAW*LEG_IND & $\begin{array}{c}0.0384^{* * *} \\
(4.53)\end{array}$ & $\begin{array}{c}0.0376^{* * *} \\
(4.44)\end{array}$ & $\begin{array}{c}0.0300^{* * * *} \\
(3.58)\end{array}$ & $\begin{array}{c}0.0326^{* * *} \\
(3.15)\end{array}$ & $\begin{array}{c}0.0433^{* * * *} \\
(5.23)\end{array}$ & $\begin{array}{c}0.0443^{* * * *} \\
(5.27)\end{array}$ \\
\hline DEP_INF & $\begin{array}{c}0.0194^{* *} \\
(2.47)\end{array}$ & $\begin{array}{c}0.0064 \\
(0.92)\end{array}$ & $\begin{array}{c}-0.0099 \\
(-1.13)\end{array}$ & $\begin{array}{c}-0.0294^{* *} \\
(-2.63)\end{array}$ & $\begin{array}{c}-0.0004 \\
(-0.08)\end{array}$ & $\begin{array}{c}-0.0102^{*} \\
(-1.67)\end{array}$ \\
\hline DEP_INF*LEG_IND & $\begin{array}{c}0.0004 \\
(0.26)\end{array}$ & $\begin{array}{c}0.0016 \\
(1.16)\end{array}$ & $\begin{array}{c}0.0036^{* *} \\
(2.13)\end{array}$ & $\begin{array}{c}0.0058^{* * *} \\
(3.14)\end{array}$ & $\begin{array}{c}0.0041^{* * * *} \\
(3.42)\end{array}$ & $\begin{array}{c}0.0051^{* * * *} \\
(4.10)\end{array}$ \\
\hline B_CREDIT & $\begin{array}{c}-0.1167^{* * * *} \\
(-3.55)\end{array}$ & $\begin{array}{c}-0.1113^{* * *} \\
(-3.81)\end{array}$ & $\begin{array}{c}-0.0904^{* * *} \\
(-2.89)\end{array}$ & $\begin{array}{c}-0.1042^{*} \\
(-1.91)\end{array}$ & $\begin{array}{c}-0.1374^{* * *} \\
(-7.35)\end{array}$ & $\begin{array}{c}-0.1427^{* * *} \\
(-7.58)\end{array}$ \\
\hline B_CREDIT*NPL & & $\begin{array}{c}0.0038^{*} \\
(1.68)\end{array}$ & & $\begin{array}{c}0.0046^{* *} \\
(2.35)\end{array}$ & & $\begin{array}{c}0.0039^{* * *} \\
(2.12)\end{array}$ \\
\hline B_CONC & $\begin{array}{c}0.0458^{* *} \\
(1.96)\end{array}$ & $\begin{array}{c}0.0365 \\
(1.45)\end{array}$ & $\begin{array}{c}0.0303 \\
(1.25)\end{array}$ & $\begin{array}{c}0.0317 \\
(1.39)\end{array}$ & $\begin{array}{c}0.0800^{* * * *} \\
(4.14)\end{array}$ & $\begin{array}{c}0.0755^{* * * *} \\
(3.88)\end{array}$ \\
\hline B_CONC*NPL & & $\begin{array}{c}0.0121^{* * *} \\
(2.08)\end{array}$ & & $\begin{array}{c}0.0169^{*} \\
(1.82)\end{array}$ & & $\begin{array}{c}0.0059^{*} \\
(1.94)\end{array}$ \\
\hline NPL & & $\begin{array}{c}-0.0106^{* *} \\
(-2.01) \\
\end{array}$ & & $\begin{array}{c}-0.0143^{* *} \\
(-2.12) \\
\end{array}$ & & $\begin{array}{c}-0.0074^{* * *} \\
(-2.94)\end{array}$ \\
\hline Industry-year effects & Yes & Yes & Yes & Yes & Yes & Yes \\
\hline F test & $3.65^{* * *}$ & $3.91^{* * *}$ & $3.62^{* * *}$ & $3.94^{* * *}$ & $7.00^{* * * *}$ & $7.20^{* * * *}$ \\
\hline \#observations & 97,981 & 97,981 & 77,917 & 77,917 & 77,414 & 77,414 \\
\hline \#firms & 17,249 & 17,249 & 14,406 & 14,406 & 13,670 & 13,670 \\
\hline Endogeneity test & $26.93^{* * *}$ & $18.90^{* * * *}$ & $6.77^{* *}$ & $11.23^{* * *}$ & $53.75^{* * *}$ & $38.30^{* * * *}$ \\
\hline Cragg-Donald stat. & 1428.99 & 2028.05 & 440,702 & 451.68 & $1,385.60$ & $2,804.67$ \\
\hline Stock \& Yogo critical value (10\%) & 7.56 & 7.56 & 7.56 & 7.56 & 7.56 & 7.56 \\
\hline
\end{tabular}

